IZA DP No. 6137

The Use of Flexible Measures to Cope with

Economic Crises in Germany and Brazil

Werner Eichhorst

Paul Marx

José Pastore

November 2011

Forschungsinstitut

zur Zukunft der Arbeit

Institute for the Study

of Labor 


\title{
The Use of Flexible Measures to Cope with Economic Crises in Germany and Brazil
}

\author{
Werner Eichhorst \\ $I Z A$ \\ Paul Marx \\ IZA \\ José Pastore \\ University of São Paulo
}

\section{Discussion Paper No. 6137 \\ November 2011}

\author{
IZA \\ P.O. Box 7240 \\ 53072 Bonn \\ Germany \\ Phone: +49-228-3894-0 \\ Fax: +49-228-3894-180 \\ E-mail: iza@iza.org
}

\begin{abstract}
Any opinions expressed here are those of the author(s) and not those of IZA. Research published in this series may include views on policy, but the institute itself takes no institutional policy positions.

The Institute for the Study of Labor (IZA) in Bonn is a local and virtual international research center and a place of communication between science, politics and business. IZA is an independent nonprofit organization supported by Deutsche Post Foundation. The center is associated with the University of Bonn and offers a stimulating research environment through its international network, workshops and conferences, data service, project support, research visits and doctoral program. IZA engages in (i) original and internationally competitive research in all fields of labor economics, (ii) development of policy concepts, and (iii) dissemination of research results and concepts to the interested public.
\end{abstract}

IZA Discussion Papers often represent preliminary work and are circulated to encourage discussion. Citation of such a paper should account for its provisional character. A revised version may be available directly from the author. 
IZA Discussion Paper No. 6137

November 2011

\section{ABSTRACT \\ The Use of Flexible Measures to Cope with Economic Crises in Germany and Brazil}

This study gives a comparative overview of labor market dynamics and institutional arrangements in Germany and Brazil with particular emphasis on industrial relations, wage setting, unemployment benefits, employment protection and vocational training. The paper shows that institutions determine the mode of adjustment to changing economic conditions and the role of standard vs. non-standard contracts. Whereas internal flexibility via shorter working time was a dominant mode of adjustment during the 2008-09 crisis in the German manufacturing sector, in Brazil such plant-level flexibility to avoid dismissals was less prominent.

JEL Classification: $\quad$ J21, J42, J52

Keywords: labor market flexibility, Germany, Brazil, working time, dismissal protection

Corresponding author:

Werner Eichhorst

IZA

P.O. Box 7240

53072 Bonn

Germany

E-mail: eichhorst@iza.org

* The authors are grateful for the support of Bradesco, CNI, Mercedes Benz, Fecomercio (São Paulo) and Sindipeças. The ideas expressed in this paper are the authors' own. 


\section{TABLE OF CONTENTS}

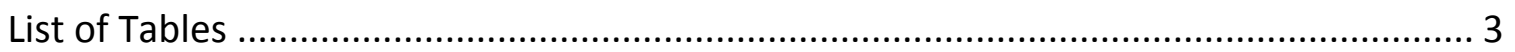

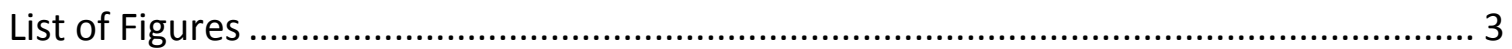

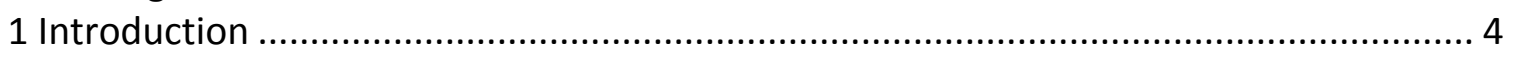

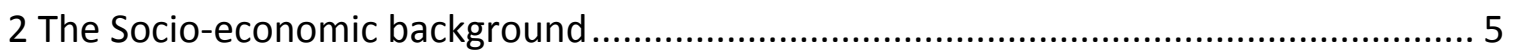

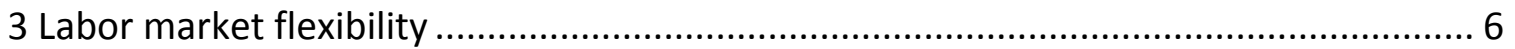

3.1 Different forms of labor market flexibility .......................................................... 6

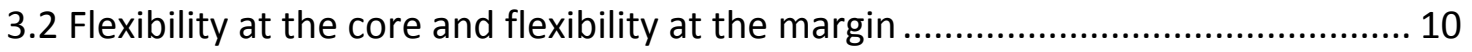

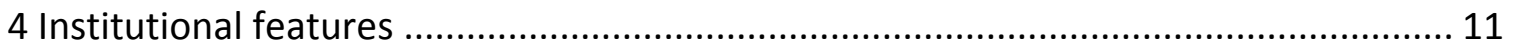

4.1 Industrial relations and wage setting in Germany........................................... 11

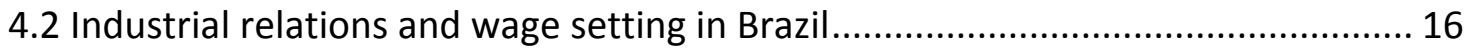

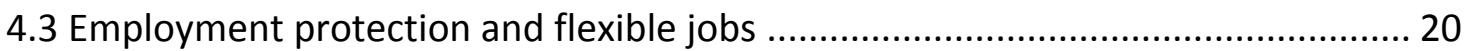

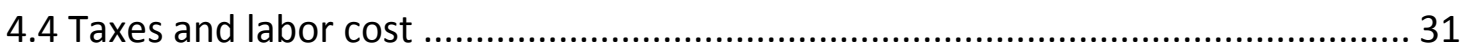

4.5 Unemployment benefits and minimum income schemes................................... 34

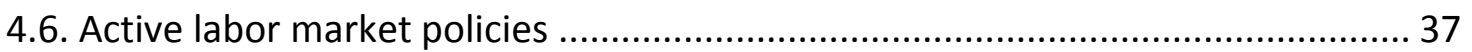

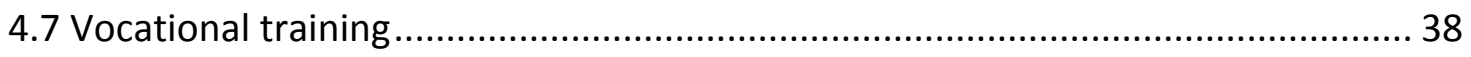

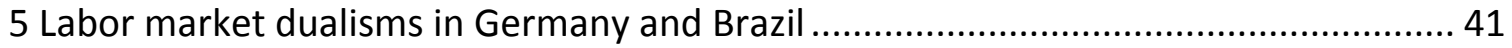

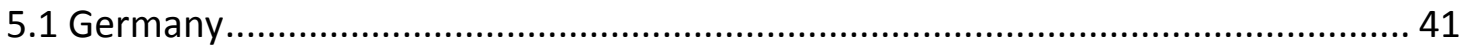

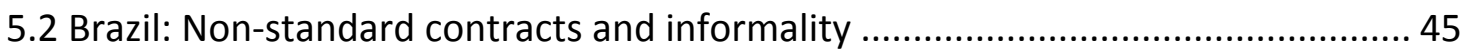

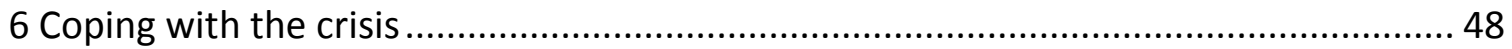

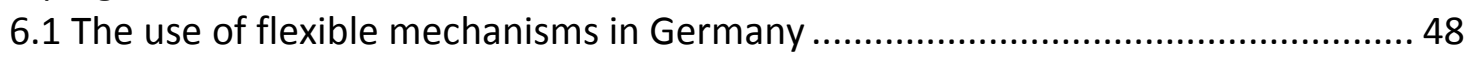

6.2 The use of flexible mechanisms in Brazil ............................................................ 51

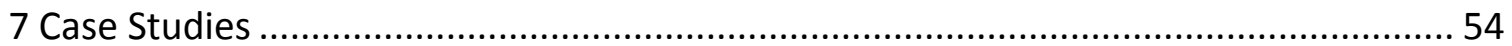

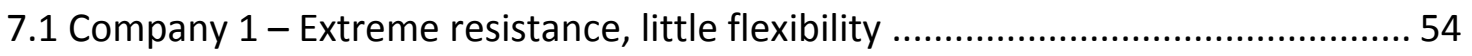

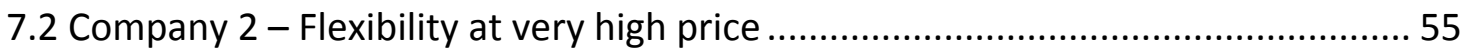

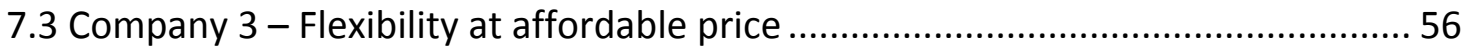

7.4 Company 4 - mild impact and no flexibility .................................................... 57

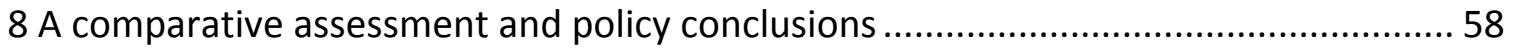

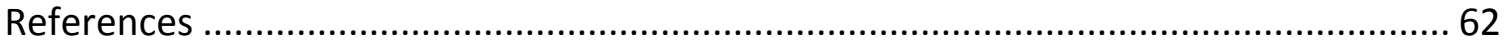




\section{List of Tables}

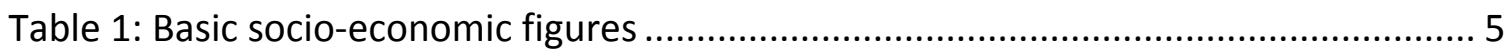

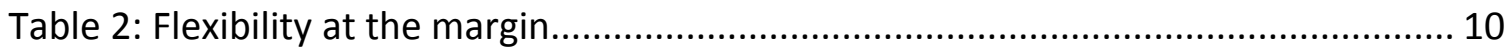

Table 3: Gross hourly minimum wages in Germany (EUR and BRL per hour) .................. 15

Table 4: Comparison of industrial relations and collective bargaining ........................... 20

Table 5: OECD Indicators of Employment Protection, 2008......................................... 24

Table 6: Cost of dismissal of an employee in Brazil who makes BRL 1,000 per month

(about EUR 435) and has worked for the company for three years................................ 26

Table 7: Labor costs in manufacturing (\% of gross wage), 2010 .................................... 32

Table 8: The cost of legal contracts in Brazil, hourly workers ...................................... 33

Table 9: Types of contract, dismissal protection and unemployment benefit coverage in

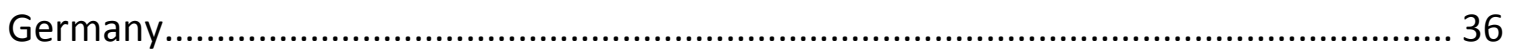

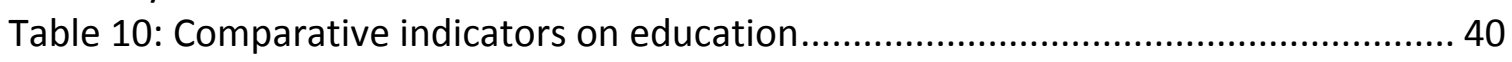

Table 11: The different components of labor market reaction in Germany .................... 48

Table 12: The different components of labor market reaction in Brazil .......................... 53

\section{List of Figures}

Figure 1: Number of cases filed in labor courts (total and concerning dismissals) and share of settlement deals in Germany, 1999-2008

Figure 2: Coverage by dismissal protection (without taking into account probationary period) in Germany, 2008 ................................................................................. 22

Figure 3: German working-age population by highest qualification (ISCED-97), 2008 ... 40

Figure 4: Structure of the working age population in Germany, 1995-2009 ................ 42

Figure 5: Non-standard work and employment growth by occupations, 1995-2009 ..... 43 


\section{Introduction}

The aim of this paper is to analyze the institutional provisions and use of flexible employment mechanisms and their impact on unemployment, standard and nonstandard employment patterns as well as informality in Germany and Brazil. ${ }^{2}$ Special attention will be given to the role these mechanisms played during the financial crisis of 2008-09.

Of course, Germany and Brazil vary greatly with regard to the structure of their economies and the rules and regulations governing labor relations. Germany, the fifth largest economy in the world, is characterized by robust export of high technology products (machines, equipment, vehicles, chemical products, etc.) and by a generally highly skilled workforce. Brazil is the eighth largest economy in the world and is characterized by its high potential as an exporter of "commodities" (minerals, soy, cotton, sugar, etc.) ${ }^{3}$ and by a mostly unskilled workforce. These difference appear in standard living measures, with per capita income in Germany-in terms of purchasing power parity (PPP) - at BRL 67,160 (EUR 29,200), more than three times that of Brazil, at BRL 18,037 (EUR 7,842) (2010 data). Furthermore, social inequality is much more pronounced in Brazil than in Germany.

Compared to other Group of twenty (G20) countries, however, Brazil and Germany have performed reasonably well in recent years - in particular during and after the 2008-09 global economic crisis, in which unemployment remained around $8 \%$ in both countries. They enjoyed, in fact, a growth in employment, whereas in several European countries, and even in the United States, job creation was anemic and unemployment was over $9 \%$. In Spain it even exceeded $20 \%{ }^{4}$

This paper explores the role of government economic stimulus and flexible labor market mechanisms during the crisis. It is reasonable to hypothesize that in Germany the wellestablished mechanisms via wage and working-time flexibility have played an important role, and that in Brazil they had a rather supporting role. The two countries have similar mechanisms, but the institutional environment and the long practice of social dialogue make them more widely used in Germany than in Brazil.

\footnotetext{
${ }^{2}$ Informality in the workplace is defined here as an absence of social security protection.

${ }^{3}$ On a smaller scale Brazil also exports machines, vehicles, airplanes and other industrial products.

${ }^{4}$ Care must be taken since unemployment figures alone are not an adequate performance measures for Brazil, where $50 \%$ of the workforce is unprotected and works "off-the-books". This is a much higher rate than Germany, where informal economic activity is estimated to be around $16 \%$ of GDP (Enste and Schneider 2011).
} 


\section{The Socio-economic background}

With a population of 195 million, Brazil has the fifth largest in the world. However, the rate the population is growing decreased from $1.8 \%$ per year in 1990 to $-0.39 \%$ in $2010 .^{5}$ Yet the total number of inhabitants in Brazil has increased by more than $25 \%$ over the last 20 years. Although Brazilians are predominantly young, the population is ageing quickly. In 1992 the proportion of elderly (aged 60 and older) was only 7.9\%, but by 2009 this figure had jumped to $11.3 \%$. The World Bank forecasts that this trend will continue, reaching 28\% in 2020 and 30\% in 2050 (World Bank 2011).

Table 1: Basic socio-economic figures

\begin{tabular}{|c|c|c|}
\hline & Germany & Brazil \\
\hline $\begin{array}{l}\text { Real GDP growth } \\
\text { (average: 2005-2008, } \\
\text { OECD) }\end{array}$ & 1.36 & 5.8 \\
\hline $\begin{array}{l}\text { GDP per capita (IMF } \\
\text { 2010) in EUR }\end{array}$ & 29.200 & 7.842 \\
\hline $\begin{array}{ll}\text { Employment } & \text { rate } \\
(O E C D, 2008) & \end{array}$ & 70.2 & 68.3 \\
\hline $\begin{array}{l}\text { Unemployment rate } \\
\text { (World Bank, 2009) }\end{array}$ & 7.7 & 8.3 \\
\hline $\begin{array}{l}\text { Population growth } \\
\text { (World Bank, 2010) }\end{array}$ & -0.2989 & 0.87578 \\
\hline $\begin{array}{l}\text { Exports in \% of GDP } \\
\text { (World Bank, 2009) }\end{array}$ & 41 & 11 \\
\hline $\begin{array}{l}\text { Employment in } \\
\text { agriculture (World } \\
\text { Bank, 2009) }\end{array}$ & 1.7 & 17.0 \\
\hline $\begin{array}{l}\text { Employment in } \\
\text { manufacturing (World } \\
\text { Bank, 2009) }\end{array}$ & 28.7 & 22.1 \\
\hline $\begin{array}{l}\text { Employment in } \\
\text { services (World Bank, } \\
\text { 2009) }\end{array}$ & 69.5 & 60.7 \\
\hline
\end{tabular}

Sources: World Bank, IMF, OECD.

\footnotetext{
${ }^{5}$ According to the census, or National Study by Sampling of Domiciles (Pesquisa Nacional por Amostra de Domicílio, PNAD) carried out by the Instituto Brasileiro de Geografia e Estatística (IBGE), the rate of participation of the group aged 16-24 fell from $16.8 \%$ in 1992 to $15.6 \%$ in 2009; the group aged 25-35 years remained practically stable at $17.9 \%$. There was an increase in the following age groups: $36-59$, from $22 \%$ to $29 \%$; and 60 and over, surprisingly, from $7.9 \%$ to $11.3 \%$.
} 
The situation in Germany is very much different. With 81 million people it is the fifteenth largest population in the world and is much older, with a median age of 44.2 years. The share of people under 30 is $30 \%$ and one third of the population is 55 years or older. Since the early 1990s the population has remained relatively constant, but a reduction is expected, with a future decline of $2.2 \%$ each year.

In terms of education, the two countries are also quite different. According to the Human Development Index, the average years of school of the adult population in Brazil is just 7.2-compared to 12.2 years in Germany. However, Brazil has made significant improvement in this area. In $199220 \%$ of the population had no education. However, by 2009 this had decreased to less than 7.5\%. During this period there was a rise in the proportion of those with university education, from $1.3 \%$ to $10.2 \%$. A substantial increase was also observed among those with an intermediate level of education (11 years), from $4.8 \%$ in 1992 to $27 \%$ in 2009 .

Brazilians staying longer at school meant that the number of those economically active grew more slowly. Although there was an increase in formal contracts over the period under study, the rate of informality still remains very high-approaching $45 \%$ of the workforce (Jacob 2010).

\section{Labor market flexibility}

Labor market flexibility is a controversial topic. It is often argued that the integration of national economies into global markets makes them more vulnerable to structural changes and therefore forces them to enhance their adaptive capacities. The openness of economies results in more frequent shocks, which requires a great deal of flexibility from the workforce in terms of occupational and geographical mobility and wage moderation. The same is true for companies facing a more volatile demand and greater pressure to adapt their head count. While some claim this challenge is best met with a maximum amount of freedom in the market, others believe in the possibility to sustain national labor market arrangements and production models. Globalization has increased the pressure on policy makers to deregulate economies, which can be seen in various reform agendas-including those affecting labor markets.

International comparisons reveal very different responses and diverging paths of flexibility which can turn out to be functionally equivalent. Countries with economies which are less market-driven but still economically successful have given rise to the hypothesis of various viable models of market adaptability.

\subsection{Different forms of labor market flexibility}

In order to capture different patterns of flexibility, we refer to a widely used typology from Atkinson (1984), which characterizes two dimensions of labor market flexibility: internal and external. Strategies which are applied inside a company represent internal flexibility and those applied to the labor market external flexibility. Flexibility either 
derives from variation of workload (numerical) or from organizational adaptability (functional). A third way is to adjust wages and labor costs to the economic situation. Considering these criteria, five types of flexibility can be distinguished.

1. External numerical flexibility means the possibility to adapt the number of employees to the economic situation with layoffs or hirings (permanent or temporary). This depends on the extent of employment protection for openended and fixed-term contracts and the quantitative availability of manpower. The latter is influenced by features of the benefit system influencing labor supply. The same is true for taxation of labor and its combined effect with the benefit system. High tax wedges and marginal effective tax rates can lead to several "traps" that provide incentives to remain inactive, unemployed or in a low-paid job.

2. Internal numerical flexibility is achieved without variations in the number of staff. It allows for an adjustment of working time via overtime or working-time accounts in order to meet a company's required capacity.

3. External functional flexibility requires a skilled workforce adaptable to structural changes. Skill mismatch in the labor market can be avoided by promoting occupational mobility through active labor market policies, in particular job placement and training. A prerequisite for an adaptable workforce is the provision of a high standard of primary, secondary and tertiary education to create a basis for life-long learning.

4. Internal functional flexibility means the ability to react to changing demand with a flexible organization of the production process. This requires broad and welleducated employees who are able to perform different tasks. Investment in firmspecific human capital via continual (internal) training is a major contribution to this type of flexibility.

5. Wage flexibility is when real wages can respond to changing macroeconomic conditions such as shocks. Rigidity results from wage-setting regimes such as statutory or collectively agreed minimum wages.

This typology identifies different modes of labor market flexibility. An underlying assumption is that the types of flexibility can support or substitute each other so that all labor markets develop some forms of adaptability. A similar level of overall adaptability can be achieved by alternative flexibility mixes.

The European phenomenon of persistent mass unemployment following the "golden" post-war era shifted the focus of comparative labor market analysis. Instead of shocks, institutional rigidities were increasingly regarded as explanatory factors for employment outcomes (Blanchard 2006). Since the 1990s institutions have been at the core of the debate about varying national labor market patterns. A large number of theoretical and empirical studies suggest an at least partly causal relationship between institutional arrangements and labor market performance (Nickell 1997, Nickell et al. 2005, Bassanini and Duval 2006). It is argued that adverse institutions lead to a persistent deviation 
from the labor market equilibrium by distorting price- and wage-setting mechanisms. In this sense, four groups of labor market institutions are typically accused of creating or increasing unemployment: the wage-setting arrangement, unemployment benefits, taxation, and employment protection. Active labor market policies form a fifth group of institutions with significant influence on employment outcomes. However, they have to be considered rather supportive than adverse.

Focusing on these "classical" institutions risks neglecting important aspects of flexibility, as they do not represent all forms inherent in the above typology. To fully understand patterns of labor market flexibility, the analysis has to be extended to additional institutional factors. The most important is education (including early-childhood education, vocational training and life-long learning). Another blind spot of most research is internal flexibility. This leads to biased results, as in many countries flexible working-time models provide a compensation for rigid hiring-and-firing practices. Besides working time, organizational aspects also make a major contribution to internal flexibility. Versatile workers provide an opportunity to respond to changing external conditions without drawing on resources from the external market.

On the whole, eight sets of external and internal labor market institutions have to be considered:

1. The most classical explanatory factor is the wage setting arrangement due to its direct influence on wage flexibility in terms of nominal and real rigidities and wage dispersion. In terms of institutions, the most relevant features are: the extent of unionization, coverage by collective agreements or binding minimum wages, and the degree of centralization and co-ordination of wage bargaining through corporatist arrangements. Wage adjustment is often seen as particularly efficient in a) decentralized bargaining structures with most wages being set at the individual or enterprise level due to the direct consideration of market forces or b) in a centralized and co-ordinated fashion which facilitates wage moderation. Hence, both centralized and decentralized regimes can be beneficial with regards to wage moderation and wage flexibility. Wage dispersion is assumed to be more pronounced in decentralized regimes with low bargaining coverage and low or non-existent binding minimum wages.

2. Employment protection, i.e. provisions for dismissal protection and restrictions on temporary employment and temporary work agencies, can influence the adaptation processes by raising layoff and hiring costs. While it stabilizes jobs and sets incentives for continual training, it can hamper adjustment to changes by reducing mobility in the labor market. Given the protection of regular employees, employment protection can lead to stronger wage pressure from labor market insiders. Employment protection can reduce the reemployment opportunities of outsiders and entrants and deepen labor market segmentation.

3. Unemployment benefits, a passive labor market policy measure, not only comprise unemployment insurance but also social assistance, different forms of disability pensions and early retirement schemes. Through the provision of 
income replacement, unemployment benefits can provide some human capital insurance for qualified workers in the early phase of unemployment. However, they may reduce job search intensity and labor supply by presenting negative work incentives and raising the reservation wage because they provide an implicit wage floor.

4. Taxes on labor can reduce labor demand and labor supply-in particular income taxes and non-wage labor costs stemming from social insurance contributions. The extent of this effect depends on the actual tax burden of employers or employees, taking wage adjustments into account. Negative effects are more likely for low-paid jobs where non-wage labor costs are not borne by the worker but by the employer.

5. Active labor market policies can facilitate a better matching in the labor market through placement support, raising productivity through publicly sponsored training and compensating for productivity deficits with hiring subsidies. By improving the human capital of the unemployed and intensifying job search through strict monitoring, they can increase competition in the labor market, help avoid bottlenecks and facilitate wage moderation. The use of active schemes helps counter potential work disincentives stemming from generous unemployment benefits. However, ineffective labor market policies can hamper employment performance due to negative tax effects.

6. Education and training affect both labor demand and supply because skilled workers are more attractive to employers and their investment in human capital raises the opportunity costs of inactivity. As a consequence, employment as well as unemployment rates are strongly correlated to the educational background. A good standard of childhood education can produce considerable long-term benefits-determining adaptability and employability over course of an individual's life. This effect is further strengthened with additional life-long learning.

7. Working-time arrangements are a functional equivalent to external numerical flexibility. Non-standard working-time models, such as overtime, part-time, flexible working hours and working-time accounts, allow for adjustment to workload peaks and slumps without hiring and firing. Depending on whether changes in working-time are compensated, such arrangements can entail significant wage flexibility.

8. Human capital investment in a firm-specific setting, i.e. the creation and maintenance of work-related skills by formal and informal adult job-related learning increases the ability to respond to changing market requirements. Shifting workers between departments, tasks or branches without the need of extensive retraining can supplement working-time flexibility as a means of internal restructuring. 


\subsection{Flexibility at the core and flexibility at the margin}

In virtually all economies the different forms of labor market flexibility are used to a varying degree by employers and workers depending on sector, firm size, skill requirements and bargaining power. In general, there is a certain divide in the use of internal vs. external forms of flexibility between core groups of workers and workers with a more marginal status in the labor market. Hence, typically open-ended contracts held by skilled workers in larger firms or core sectors of the economy are covered by employment protection, full social protection, collective agreements and more elaborate forms of internal flexibility. Other groups of the workforce work under more insecure conditions (in terms of external and wage flexibility) to help contain labor costs and keep them variable. Different forms of highly flexible employment can be observed at the margins of the labor market: fixed-term, agency work, part-time, selfemployment, low pay (also sometimes supported by public policies) and informal work.

Table 2: Flexibility at the margin

\begin{tabular}{|c|c|c|c|}
\hline $\begin{array}{l}\text { Paths towards labor } \\
\text { cost reduction }\end{array}$ & $\begin{array}{c}\text { Type of labor costs } \\
\text { affected }\end{array}$ & $\begin{array}{c}\text { Types of } \\
\text { employment }\end{array}$ & $\begin{array}{l}\text { Dimension of labor } \\
\text { market divide }\end{array}$ \\
\hline $\begin{array}{l}\text { Defection from open- } \\
\text { ended contracts }\end{array}$ & Turnover costs & $\begin{array}{c}\text { Fixed-term contracts, } \\
\text { agency work }\end{array}$ & $\begin{array}{l}\text { Employment } \\
\text { stability }\end{array}$ \\
\hline $\begin{array}{l}\text { Defection from full- } \\
\text { time jobs }\end{array}$ & Non-wage labor costs & $\begin{array}{c}\text { Part-time, } \\
\text { particularly marginal }\end{array}$ & $\begin{array}{l}\text { Social security } \\
\text { coverage }\end{array}$ \\
\hline $\begin{array}{c}\text { Defection from } \\
\text { dependent } \\
\text { employment }\end{array}$ & $\begin{array}{l}\text { Wage, non-wage and } \\
\text { turnover costs }\end{array}$ & $\begin{array}{c}\text { Self-employed } \\
\text { (without employees) }\end{array}$ & $\begin{array}{c}\text { Emp. stability, } \\
\text { wages, and social } \\
\text { security }\end{array}$ \\
\hline Wage dispersion & Wage costs & All & Wages \\
\hline $\begin{array}{l}\text { Government- } \\
\text { sponsored labor } \\
\text { cheapening }\end{array}$ & Wage/non-wage costs & $\begin{array}{c}\text { All, special } \\
\text { contracts/programs }\end{array}$ & $\begin{array}{c}\text { Limited mobility to } \\
\text { unsubsidized jobs }\end{array}$ \\
\hline Informal employment & Wage/non-wage costs & All & $\begin{array}{l}\text { Informal status, } \\
\text { exclusion from } \\
\text { social protection }\end{array}$ \\
\hline
\end{tabular}




\section{Institutional features}

\subsection{Industrial relations and wage setting in Germany}

The current reappraisal of the German system of industrial relations can only be understood when taking into account its historical roots and the development over the last 20 or 30 years. This major restructuring took place within a remarkably stable institutional environment stemming from the post-World War Two period. Since then Germany has had a unique dual system to represent workers' interests: corporate and plant-level co-determination, and collective bargaining. Co-determination at the company level was first introduced in 1951 with the Coal, Steel and Mining Codetermination Act. Even to date, incorporated companies in the coal, steel and mining industries with more than 1000 employees have equal representation of shareholders and workers in supervisory boards. Furthermore, in mining and steel companies the human resource director can only be appointed with the consent of the workers' representatives. But co-determination at the company level is not restricted to the shrinking sectors of mining and steel production. All incorporated companies with more than 500 employees are covered by the 1952 Works Constitution Act, which stipulates that one third of the supervisory boards should be employee representativesnowadays affecting about 1,500 firms. The 1976 Co-determination Act established equal numbers of worker and shareholder representatives in incorporated companies with more than 2000 employees-currently affecting around 700 companies. However, in a stalemate the head of the supervisory board, named by the shareholders still has the decisive vote.

While company-level co-determination focuses on more general supervision of the management, a more direct influence of workers' representatives on employment and working conditions stems from co-determination at the plant level. This is also regulated by the 1952 Works Constitution Act. In contrast to supervisory board representation, codetermination at the plant level is voluntary and depends upon the initiative of workers who have the right to organize a formal election in order to set up a works council, which only consists of employees. Works councils only exist in about $10 \%$ of all plants, mainly medium-sized and larger ones. Around $45 \%$ of all employees in the private sector are currently represented by a works council in Western Germany and about 38\% in Eastern Germany. German works councils have a strong position with regard to enterprise-based social and human resource policies regarding internal reorganization, the hiring and the dismissal of individual employees, the use of non-standard forms of employment and working-time arrangements. Company level agreements between employers and works councils play a crucial role in shaping the staffing strategies of firms and their adjustment to structural or business cycle variation. However, German legislation calls for constructive cooperation between works councils and employers and prohibits strikes initiated by works councils at the plant level. 
Works councils are not entitled to enter into negotiations on issues which are usually regulated by collective agreements. The 1949 Collective Bargaining Act stipulates that collective bargaining take place mainly at the sectoral and sometimes regional level. A fundamental principle is the autonomy of employers' associations or single employers on the one hand and trade unions on the other hand to enter into negotiations on working conditions - in particular wages and working time-without interference from the government. This also implies that collective agreements are only binding to workers and employers that are members of a negotiating party, i.e. a trade union or an employers' association. There is no statutory arbitration procedure but most sectors have joint dispute resolution mechanisms based on a bilateral agreement which provides for a neutral interlocutor. In most cases, sometimes after many strikes and lock-outs, this procedure has proven successful. Except for small-scale token strikes, strikes are only legal if either regular negotiations or arbitration have failed and a majority of trade union members have voted in favor. Employers can respond with lockouts.

Since its establishment, the German system of collective bargaining has benefited from the organizational strength of the social partners. On the one hand Germany has a quite encompassing system of employer associations at sectoral and regional level as well as one national peak association. On the other hand, and in contrast to many other European countries, the vast majority of German trade unions is politically unified and adheres to one dominant peak association. The most powerful trade unions are for metal working, auto industry, chemical industry and the public sector. These sectors usually set the pace for regular (usually annual) bargaining rounds. Neither peak associations, however, are directly involved in collective bargaining but rather focus on political lobbying and internal coordination. Tripartite national social dialogue has not been a major element in German.

The system of industrial relations can be seen as a major pillar of Germany's post-war economic success. It ensured a fair distribution of income gains and a low level of societal conflict as can be seen from the low intensity of strikes and lock-outs during most of the post-war period. Things became more difficult and contentious in the aftermath of the oil price shocks in the 1970s and 1980s. In this phase not only the level of conflict increased due to harsher distributional struggles, but also more fundamental criticism was raised against the established system of collective agreements and codetermination. This was now considered by many academic and business observers as being too rigid, impeding timely adjustment to more intense global competition and endangering the international competitiveness of German industry.

In contrast to some expectations at the time, the German system of industrial relations did not completely vanish, but instead underwent recalibration and reform. This began with a significant decline in the coverage by collective agreements-particularly following reunification. For example, sectoral collective agreements affected $69 \%$ of West German and $56 \%$ of East German workers in 1996-nowadays 56\% and 38\%, respectively. The working conditions of a further 9(13)\% of all workers are based on enterprise-level agreements, with 19 (24)\% of all workers employed by companies using 
collective agreements as a guideline. Around $36 \%$ of all West German and $49 \%$ of all East German workers are employed outside any agreement. Bargaining coverage is still high in traditional strongholds, such as larger companies in manufacturing -in particular metalworking or the chemical industry, the energy sector, construction, banking and insurance and the public sector. It is much lower in most private services and smaller companies. Lower bargaining coverage is also an indirect consequence of declining trade union density, which decreased from $30 \%$ in the mid-1990s to only $19 \%$ in 2008. Shrinking membership triggered trade union mergers, resulting in "conglomerate" unions covering more than one sector. Small independent unions representing powerful groups of workers remained either stable or grew. The last 20 years has also seen fewer employers as members of sectoral employer associations. As a consequence, Germany now has quite significant "liberal" segments of employment without bargaining coverage and effective worker representation. Smaller companies, recent start-ups and many firms in the private service sector operate outside the institutional core of the German system of industrial relations-without collective bargaining, works councils, or company level co-determination.

However, the classical model of German collective bargaining and co-determination continues to characterize manufacturing, which can be seen as a major contributor to social peace and fruitful interaction between management and employees. In general, this dense institutional network has facilitated organizational adjustment of companies to a volatile economic environment. In particular, works councils, while bringing in the perspective of workers, have often acted pragmatically as co-managers trying to stabilize employment of the core workforce and smooth the effects of company restructuring. Since the mid-1990s establishment-level negotiations have expanded both regarding their range and their scope, leading to plant-level "alliances for jobs" based on concession bargaining between works councils and management. Sometimes works councils and employers have undermined sectoral collective agreements in order to maintain employment, exploiting and even stretching beyond so-called "opening clauses", which were then introduced in order to allow for pay or working-time deviations in particularly difficult situations. As a response, collective agreements negotiated between sectoral trade unions and employer associations became more flexible themselves, allowing for more discretion at the company level.

With hindsight one can argue that the greater degree of flexibility and growing room to manoeuver at the firm level helped stabilize the system of collective agreements to some extent. This development contributed to innovative models of working-time flexibility, including working-time accounts and more pay flexibility in exchange for employment stability. In combination with modest pay increases in collective agreements over most of the period since the 1990s, this has led to employment growth and a very moderate development of real wages in Germany. Furthermore, plant-based strategies to stabilize the highly skilled and productive core workforce contributed to the emergence of a secondary segment of workers on fixed-term contracts or temporary agency work, which are treated differently both with regard to employment 
stability and remuneration. In such a system the marginal workforce takes a disproportionate share of employment risks.

This dual pattern of adjustment also became apparent during the most recent economic crisis, which heavily affected export-oriented manufacturing in Germany-a traditional stronghold of plant-level worker representation. On the one hand, the skilled core workforce was safeguarded by mechanisms of internal adjustment, such as deferred wage increases and shorter actual working times, which could be implemented via fewer overtime hours, the consumption of surpluses on working-time accounts and a publicly subsidized short-time work scheme. The different forms of working-time reduction managed to save about 350,000 full-time equivalent positions. On the other hand, manufacturing employers quickly laid off an equally significant number of around 300,000 temporary agency workers before rehiring them in the first phase of economic recovery.

Notwithstanding its recalibration, the current state of affairs is not necessarily a stable one. Some issues remain which concern the declining scope and growing disparity of collective bargaining. This has led to more diversity regarding pay and working conditions. The German system of co-determination at the plant level has actively contributed to the further dualization of the labor market protecting core workforces on the one hand and burdening marginal workers with higher risks on the other. Employers and works councils have established a system of quite favorable working conditions and internal flexibility to stabilize shrinking core workforces while shifting substantial labor market risks on the marginal workforce, subcontractors and in particular temporary agency workers which operate on collectively agreed wages significantly below sectoral agreements of user companies. These lead to new forms of tensions both within firms and in the labor market in general.

However, there has been a strong tendency towards more individualized bargaining on wages and other working conditions. In an economy characterized by skills-based technological change and demographic ageing, skilled workers are in position to negotiate on their own behalf outside and on top of collectively agreed standards. Sectoral collective agreements are becoming less and less relevant for them. Furthermore, as a consequence of the general weakening of "conglomerate" unions representing a variety of occupations, independent unions have grown in importance. They are increasingly successful in organizing small but powerful constituencies, such as hospital doctors, pilots and train drivers, and in negotiating more favorable standards on their behalf. This development undermines the general principle to have only one union per sector or per company. Aggressive, small unions tend to raise the level of competition, eventually leading to more strikes and some leapfrogging on wage increases.

However, Germany has experienced a steep increase in jobs with low pay, in particular in those subsectors of the service economy where collective bargaining coverage is low due to structural weaknesses of trade unions and employer organizations. As a result, trade unions, which used to be keen on their right to negotiate wages and working 
conditions autonomously, have begun to argue in favor of a general statutory minimum wage, calling for a stronger responsibility of the state for setting minimum standards in the labor market. Yet no political agreement on a national minimum wage has so far been reached. However, policy makers from different political parties were able to agree on a compromise to expand the number of sectors where collectively agreed minimum wages-already covering at least half of all employees-would be made binding for all.

Table 3: Gross hourly minimum wages in Germany (EUR and BRL per hour)

\begin{tabular}{|c|c|c|c|c|}
\hline & West & & East & \\
\hline Industry sector & EUR & $B R L$ & EUR & BRL \\
\hline Construction & $\begin{array}{l}\text { Minimum wage I: } 11.00 \\
\text { Minimum wage II: } 13.00\end{array}$ & $\begin{array}{l}25.30 \\
29.90\end{array}$ & 9.75 & 22.43 \\
\hline Roofing & 10.80 & 24.79 & 10.80 & 24.79 \\
\hline Electrical & 9.70 & 22.31 & 8.40 & 19.32 \\
\hline Industrial cleaning & $\begin{array}{l}\text { Wage group } 1: 8.55 \\
\text { Wage group } 6: 13.33\end{array}$ & $\begin{array}{l}19.77 \\
30.66\end{array}$ & $\begin{array}{l}\text { Wage group 1: } 7.00 \\
\text { Wage group 6: } 8.88\end{array}$ & $\begin{array}{l}16.1 \\
20,42\end{array}$ \\
\hline Painting and varnishing & $\begin{array}{l}\text { Unskilled workers: } 9.75 \\
\text { Skilled workers: } 11.75\end{array}$ & $\begin{array}{l}22.43 \\
27.03\end{array}$ & 9.75 & 22.43 \\
\hline Old-age care & 8.50 & 19.55 & 7.50 & 17,25 \\
\hline Security services & 7.95 & 18.29 & 6,53 & 15,02 \\
\hline Laundry services & 7.80 & 17.94 & 6.75 & 15,53 \\
\hline Temporary agency work & 7.79 & 17.92 & 6.89 & 15.85 \\
\hline
\end{tabular}

Source: Bundesarbeitsministerium, as of September 2011.

Since the mid-1990s such generally binding sectoral minimum wages used to cover only the construction sector, but now they also set a minimum level in security firms, cleaning and laundry services, waste management, further education and old-age care. If such agreements are missing due to insufficient bargaining coverage or the nonexistence of collective bargaining, a specific expert committee is authorized to set a sectoral minimum wage, but this has not yet been the case in practice. A peculiar case is temporary agency work, where sectoral collective agreements exist and allow for 
deviations from the principle of equal pay, but wage scales are significantly below the standards applicable to user companies. While the binding minimum wage for this sector brought in line different competing standards as of May 2011, the most significant issue is to narrow the wage gap between agency workers and permanent staff. This is a good example of the most important challenge the German system of industrial relation is facing: reconciling the flexibility needed for job creation and competitiveness on the one hand with a fair distribution of economic risks and benefits on the other.

\subsection{Industrial relations and wage setting in Brazil}

The process of collective bargaining in Brazil is quite different from Germany. The union organization in itself is very unique: employees and employers are organized under the rubric of labor unions and employer unions, respectively, and according to a list of occupations and economic categories defined by law (Pastore 2003, Nascimento 2005). Unions of both kinds are organized in a geographically hierarchical fashion: individual unions at the county or municipal level, federations at the state level, and confederations at the national level. Together they form a confederated system as defined by the Brazilian constitution. All unions must be registered with the Ministry of Labor, making them highly dependent on the government. ${ }^{6}$

Still more unique is the financial support of unions. Registered employees (formal segment) and employers are obliged to contribute to their respective unions, regardless of their personal preferences or affiliations. ${ }^{7}$ Although all employees are legally unionized, fewer than $20 \%$ are members by choice. This is not the case in the public sector, where the figure is closer to $50 \% .{ }^{8}$ With respect to employers, voluntary affiliation is less than $10 \%$ in most sectors, although again, all make the compulsory contribution. All of them, however, receive contributions from their representatives, which is why unions are considered good businesses and leadership positions hotly disputed. ${ }^{9}$ Their revenues are guaranteed by law, ensuring their perpetual solvency. Hence, union leaders have no incentive to improve the performance of their unions as representative bodies.

The labor unions of the more advanced sectors (metal working, banking, chemicals, etc), however, have greater union density-around 70\%. Labor unions since the late 1980s have organized themselves in overarching, multisector structures, called centrais sindicais. In 2008, Law 11.648 defined the centrais sindicais as organizations that can act in tripartite negotiations ${ }^{10}$ and guaranteed them a revenue equal to $10 \%$ of labor union

\footnotetext{
${ }^{6}$ Brazil has not ratified Convention 87, which grants full freedom to organize unions.

${ }^{7}$ Employees pay one day of salary per year and employers pay a proportion of their firm's capital.

${ }^{8}$ Authors' estimates.

${ }^{9}$ Elected employees cannot be dismissed from the time their candidacy begins until two years following the end of their mandate. There are many cases in which these employees can be elected in perpetuity.

${ }^{10}$ However, the law has not granted these entities the status of unions. They cannot sign agreements or take legal action against businesses.
} 
contributions. In the same year the Ministry of Labor approved an administrative procedure through which the federations and the confederations can be organized on a different basis, i.e. by union affiliation rather than sector belonging. One result of this change is that the share of the union contribution going to the centrais sindicais depends on the number of affiliated unions and federations at the base of the structure, ${ }^{11}$ resulting in a rush to create ever more unions at the base to guarantee a generous revenue stream.

In Brazil the constitution assigns the responsibility for employee collective bargaining to labor unions. But in fact there is limited space for negotiations. The law operates as a floor for most rights, and there are only two rights that can be bargained upward and downward: salaries and profit sharing.

Two types of agreements can be reached through bargaining: acordo coletivo and convenção coletiva. The acordo coletivo is established between the union which represents the employees of a particular company and its management. The convenção coletiva is established among one or more employee unions and one or more employer unions. ${ }^{12}$ The acordos [agreements] and convenções [conventions] must be registered with the Ministry of Labor, which tracks the main tendencies of the agreements.

The centrais sindicais, with the help of DIEESE (a research and training organization supported by the labor unions), assist the unions in negotiations. In the formalized segments of the labor market, most employees are covered by collective agreements. In the informal segments organized negotiations do not take place, and salaries tend to follow the minimum wage laws. Informal employees also tend to receive 13 months of salary (13th salary), as well as some vacation benefits, but do not receive social security benefits.

Brazil does not have works councils along the lines of Germany. According to the constitution, workers are entitled to representation only in firms with more than 200 employees but very little representation is in operation. Company shop stewards are present in a few sectors, such as the automobile industry in São Paulo. In plants with more than 20 employees, workers can participate in Internal Committees for Accident and Disease Prevention (Comissão Interna de Prevenção de Acidentes, CIPAs). Members enjoy job stability during their election to the committees and two years after completion of their term.

The sense of mistrust in Brazil that was prevalent in the beginning of the 1930s, when the country began to industrialize, led the government to forcefully intervene in labor relations and establish detailed rules governing the employee-employer relationship, with very little margin for open negotiations. This tradition became firmly rooted over

\footnotetext{
${ }^{11}$ The Supreme Court is currently examining whether this procedure complies with the constitution.

${ }^{12}$ The two types of agreements are usually combined. Wages and general working conditions are bargained at the sectoral level and specific provisions (working hours, personal leave balances, profit sharing, etc.) are negotiated within each individual company. The convenções coletivas can cover one intra-state administrative division or an entire state. In a few sectors, such as banking, negotiations are carried out at the national level.
} 
time, and even now, labor relations are highly legislated and the object of heavy government intervention and excessive insularity (Robortella 2011).

In Brazil the minimum wage and the state salaries (pisos estaduais) are set by law. The level of the national minimum wage is set annually by the president and approved by the national congress. For 2011 it has been set at BRL 545 per month (EUR 237). The piso estadual is intended for workers whose minimum wage is not established by specific legislation or collective contracts. The value is proposed by state governors and approved by the legislative assembly of each state.

Other salaries are adjusted by collective bargaining and labor agreements. In times of crises, wage flexibility is provided by Law 4.923/1965, which imposes four requirements. Any attempt to reduce salaries: (a) the company must provide convincing proof that it is facing grave economic difficulties; (b) the reduction must be negotiated with the appropriate union; (c) the period of reduced wages must not exceed three months; and (d) the reduction must not exceed $25 \%$ of the current salary level. This provision is used in extreme cases only. Employers are afraid of having the agreement successfully challenged in court if they fail to convince the judge or produce the necessary proof.

In addition to the minimum wage, state minimums and negotiated wage floors, Brazilian law guarantees that employees receive one month's salary as a Christmas bonus (13th salary) and ensures that employers pay workers an amount equal to one third of their monthly salary when they take their 30-day vacation. Formally registered employees are entitled to additional compensation for work hours exceeding an eight-hour day or a 44hour week-at a rate of time-and-a-half, with an additional $20 \%$ for night work. ${ }^{13}$ Based on collective bargaining, however, the percentage tends to be higher.

Laws also specify considerably shorter work days for certain professions: elevator operators, switchboard operators, miners, bank tellers and cinema staff have a six-hour day, lawyers, physicians and teachers who give back-to-back classes are required to work only four hours each day.

Experience with labor flexibility in Brazil is new and limited. Traditionally, labor relations took place-and still do-within a rigid framework created by the labor code (Consolidação das Leis do Trabalho, CLT) from 1943-the time of the dictatorial regime of President Getulio Vargas (Pastore and Skidmore, 1985). The CLT establishes a myriad of social protection and regulates the organization of employees and employers, collective bargaining and conflict resolution. Contrary to Germany, the Brazilian system sharply limits the role of collective bargaining in the attainment of rights, most of which are established by laws. The Federal Constitution of 1988 expanded the range of labor obligations. Finally, the courts themselves have laid down a vast amount of jurisprudence, and the role of the state is still significant (Pastore, 2011).

Collective and individual conflicts are resolved exclusively by courts at the local, regional and national levels. About $50 \%$ are solved at the local level in less than 12 months. The

\footnotetext{
${ }^{13}$ Nearly $20 \%$ work more than 44 hours per week; $27 \%$ work exactly 44 hours, and the rest work fewer than 44 hours. In fact, $40 \%$ work 40 hours per week arranged by negotiation.
} 
rest proceed to the next steps and can take up to 7-8 years to be resolved. ${ }^{14}$ Courts adjudicate some 2 million cases each year (França 2011). This veritable industry of grievance and conflict, ironically, has been a boon to all parties, allowing them to avoid responsibility for unwanted outcomes or unpopular decisions (Zylberstajn 2005).

After the Plano Real (1994), which succeeded in drastically reducing inflation, Brazil reduced the number of strikes to approximately 300 per year, compared to more than 2,000 during the hyperinflation period (1980-94). In addition, the market liberalization and the privatization of state companies contributed to a reduction of strikes-except in the public sector, where strikes are limited by law but are more frequent in practice.

A unique feature of Brazilian system is the possibility of courts ruling contracts agreed by the parties in collective bargaining as invalid. This has been a source of judicial insecurity to both employers and employees, who never know whether the judges will approve the agreements.

Claimants can sue at no cost, creating an additional incentive to litigate, and an additional disincentive to negotiate, even in relatively trivial matters. Relationships between employees and employers tend to be marked by mutual mistrust. Court intervention in strikes reduces the pressure that labor movements put on management.

The Ministry of Labor offers a mediation service which has a limited efficacy in ending industrial action. There also exists an arbitration law, but its application in the area of labor is often blocked by judges and by the Labor Prosecutions Office (Ministério Público do Trabalho) and solicitors-general (procuradores). They tend to consider labor rights as non-negotiable obligations. So labor arbitration has a slow progress in Brazil.

\footnotetext{
${ }^{14}$ The courts hear cases brought by both formal and informal employees, most of them challenging the grounds for their dismissal.
} 
Table 4: Comparison of industrial relations and collective bargaining

\begin{tabular}{|c|c|c|}
\hline & Germany & Brazil \\
\hline General approach & $\begin{array}{l}\text { Collective bargaining } \\
\text { autonomy and legislation } \\
\text { on framework and } \\
\text { co-determination rules }\end{array}$ & $\begin{array}{l}\text { Heavy legislation and } \\
\text { collective bargaining } \\
\text { subjected to labor court } \\
\text { interventions }\end{array}$ \\
\hline Bargaining approach & $\begin{array}{l}\text { Pattern bargaining, mostly } \\
\text { at sectoral level, increasing } \\
\text { plant-level autonomy }\end{array}$ & $\begin{array}{lr}\text { Sectoral/regional } & \text { levels. } \\
\text { Some room for plant-level } \\
\text { bargaining } \\
\text { contradicting not } \\
\text { sectoral/regional } \\
\text { agreements }\end{array}$ \\
\hline Trade union density & $18.6 \%^{a}$ & $\begin{array}{l}\text { total: } 21.0 \%^{b} \\
\text { formal sector } 30.5 \%^{b}\end{array}$ \\
\hline Bargaining coverage & $61 \%^{c}$ & $\begin{array}{l}\text { Sectoral/regional } \\
\text { agreements cover } \\
\text { practically } 100 \% \text { of the } \\
\text { formal sector. } \\
\text { Informal sector follows a } \\
\text { few bargained clauses of } \\
\text { the formal sector } \\
\text { (Neri/Fontes 2010). }\end{array}$ \\
\hline
\end{tabular}

Sources: ${ }^{\mathrm{a} O E C D ;}{ }^{\mathrm{b}}$ PNAD microdata; ${ }^{\mathrm{c}} \mathrm{EIRO}$.

\subsection{Employment protection and flexible jobs}

\section{Germany}

The German system of dismissal protection goes back to an act of the early 1950s (KSchG) and has not changed much ever since. The most important limitation of the managerial prerogative to dismiss at will is laid down in Section 1, which stipulates that dismissals are only valid if important reasons can be given by the employer (e.g. urgent business reasons). Establishing this is rather complex. As dismissed workers have the right to appeal in court and the outcome of judicial verification is difficult to predict, the system is characterized by considerable uncertainty. All the more since the employer has to observe a complex mix of "social selection criteria", such as tenure, age and child support obligations. If, and only if, a dismissal is decided to be unjustified, does the 
employer have to pay severance pay, which generally amounts to half the monthly salary per year of tenure. However, it can be much higher. Works councils cannot formally veto dismissals, but there are procedural requirements which have to be fulfilled, such as the works council being informed about the dismissal and the reasons. Formal errors in this procedure make the dismissal invalid and the dismissed worker has the right to be re-employed or-much more frequently-compensated. By and large, the German system of dismissal protection provides a high level of protection to workers, but imposes costs and uncertainty on employers. Practically, the pressure to settle for compromise (i.e. voluntary severance payments) is rather high. Filing a lawsuit against dismissal is easy and cheap and therefore takes place frequently, and trade unions provide legal assistance to their members. At the first level a professional judge is supported by two lay judges, one appointed by the trade union, one by employers. Even before a formal judgment is made, the duration of dismissal procedures is quite short. Nevertheless, the case workload is high.

Figure 1: Number of cases filed in labor courts (total and concerning dismissals) and share of settlement deals in Germany, 1999-2008

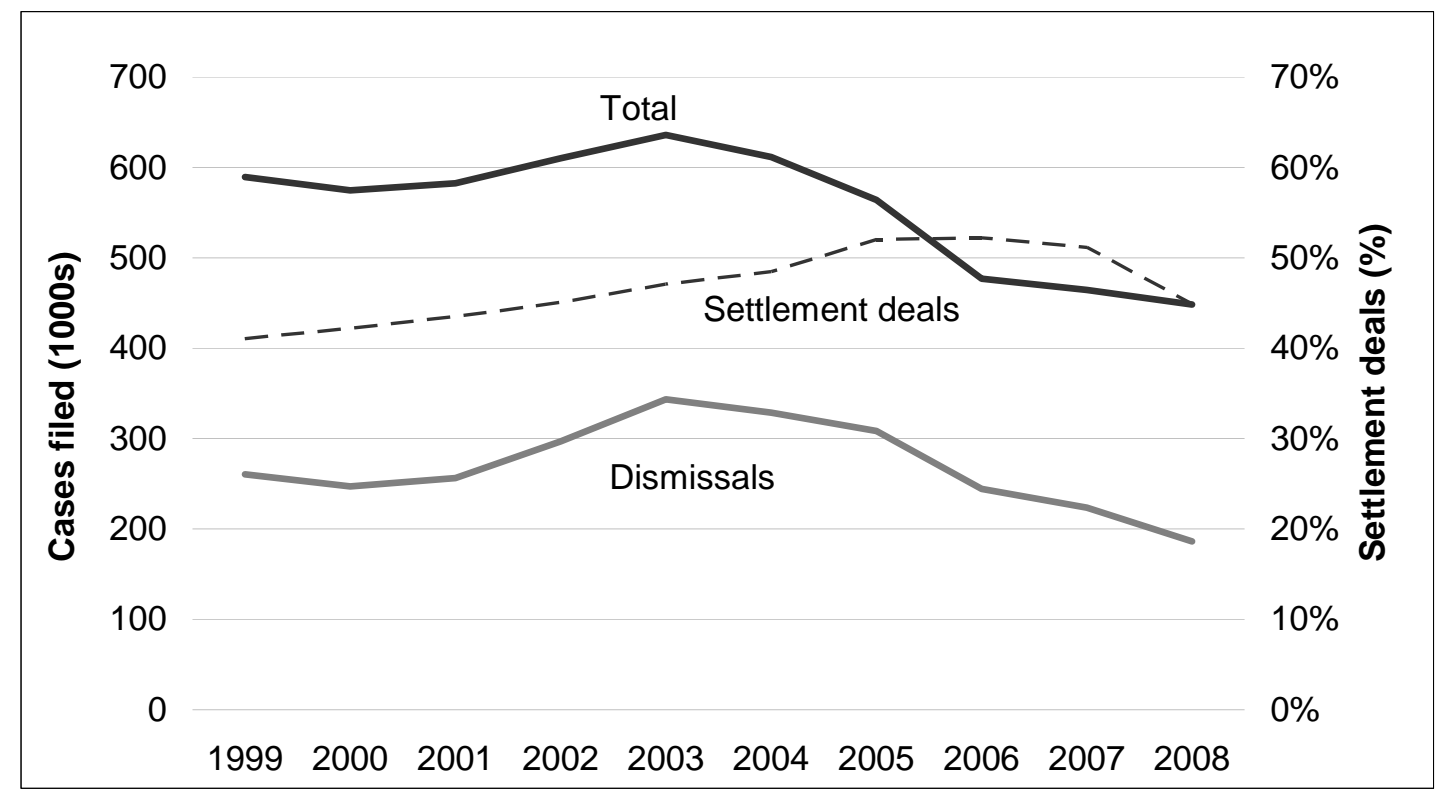

Source: Statistisches Bundesamt (2009).

However, dismissal protection coverage is not universal. Since 2004 it only affects companies with more than ten employees (previously five employees). Excluding workers in small enterprises, civil servants, self-employed and temporary workers, Figure 2 shows that approximately $60 \%$ of the German workforce is covered by dismissal protection. 
Figure 2: Coverage by dismissal protection (without taking into account probationary period) in Germany, 2008

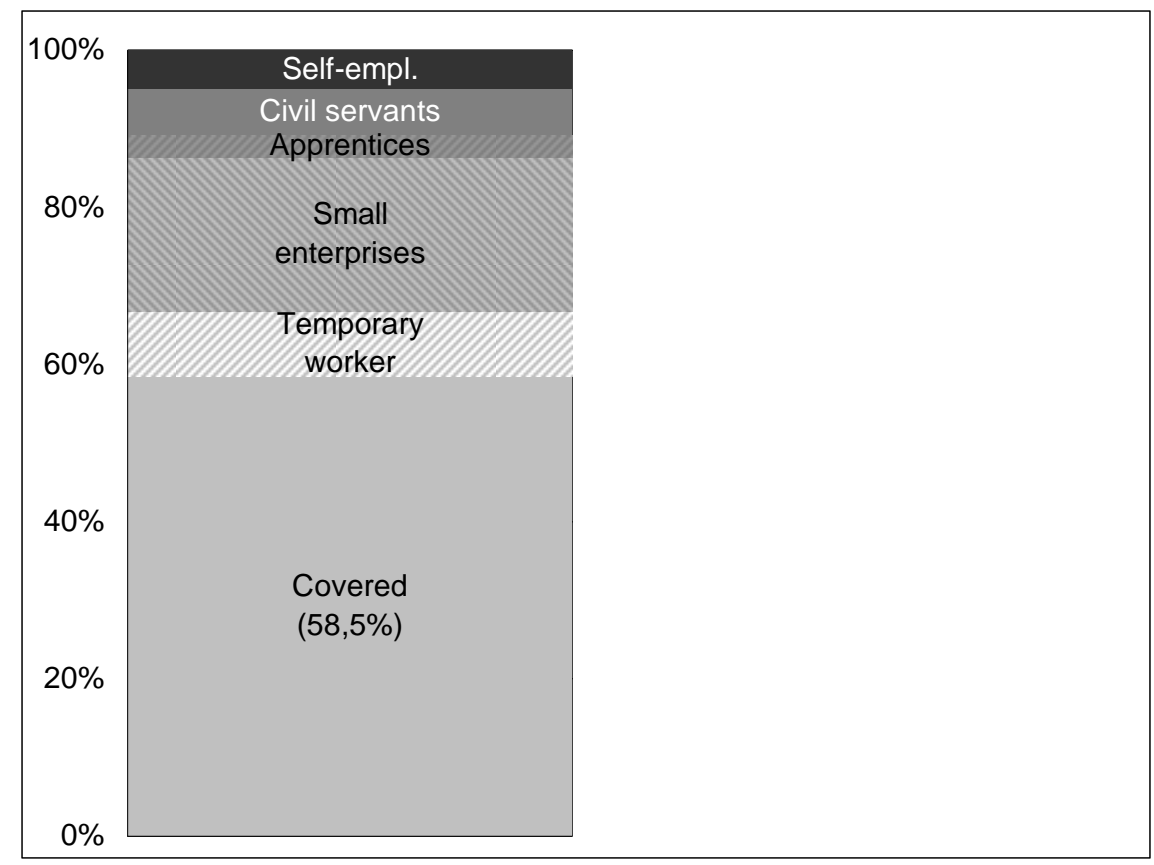

Source: GSOEP, own calculations.

\section{Flexible types of employment in Germany}

Agency work was liberalized substantively in the past. The most significant were the Hartz reforms, in which major restrictions imposed on agency work were removed, making it possible to assign agency staff to an individual company for an indeterminate duration. This had previously been restricted to two years. Moreover, before the Hartz reforms there had been a ban on synchronization and re-employment, so that temporary work agencies could not hire on fixed-term contracts with the same duration as the assignment to a user company. They were also unable to repeatedly hire the same worker after spells of unemployment. Changes in the course of the Hartz reforms meant that both these options were made available. At the same time, the principle of equal treatment regarding pay and other working conditions was introduced. However, deviations from equal pay are possible if the working conditions and wages of agency workers are regulated by specific collective agreements for temporary agency work. In fact, the sectoral collective agreements reached established a wage scale significantly below those applicable to the companies-most notably in routine jobs in manufacturing, where agency work is most prominent. Hence, there is a wage gap between agency staff and regular employees within the same establishment. For comparable tasks two categories of workers can be employed at different wages for an unlimited period of time. Not surprisingly, the transition from agency work to direct employment is rare. It was only recently that a minimum wage for agency workers was 
agreed upon, which is to enter into force soon. It will, however, still be considerably lower than the company level.

A well-established way to circumvent the costs of dismissal is the use of fixed-term contracts. For a long time fixed-term contracts used to be conditional upon a valid reason, such as substituting permanent staff. In 1985 fixed-term contracts without such a reason were legalized for the first time, however, with strict regulation. After several waves of deregulation, fixed-tem contracts now can last up to two years without the need for a valid reason. For a longer period they are lawful if either there is a special reason (e.g. replacement during parental leave, project-related work, limited funds available) or if older unemployed are hired. Specific regulation applies to the public sector, in particular academia. As a general principle, fixed-term jobs are fully integrated into social security and collective agreements and benefit from strong employment protection for the duration of the contract. However, despite equal treatment a certain wage gap between fixed-term and open-ended contracts can be observed empirically.

Freelance or self-employment is a highly flexible form, which operates outside collective agreements, provisions on employment protection and most elements of social insurance. Self-employed can continue to contribute to pension funds and unemployment funds on a voluntary basis, but the clients of freelancers are not obliged to pay employer contributions on their behalf. Self-employed who do not contribute to social insurance on a voluntary basis or to private insurance are only covered by the German general minimum income support scheme. The situation is different for selfemployed which have only one client or are integrated into the hierarchical structure of their customer's business. Under these circumstances they are considered "bogus selfemployed" and treated as dependent employees, with full liability for employee and employer contributions to social insurance. In Germany, there are no general restrictions on out-sourcing to agency work or self-employed, in fact, self-employment has been promoted by heavy subsidization of start-ups in the mid-2000s and by the liberalization of a number of traditional crafts where "master's status" is no longer needed when setting up an independent business.

An important strategy to avoid firing costs when adapting the work process is workingtime flexibility. This can either be achieved by working-time accounts or by employing part-time workers. Working-time accounts have become very important in Germany and substantially contributed to the decent performance in the recent economic crisis. The most important effect of working-time accounts is that overtime is not paid at a higher rate but as time in lieu. This makes numerical flexibility much cheaper than in the past. If variation in workload is predictable, part-time is an attractive option for many employers. Part-time workers earning more than EUR 400 (BRL 920) gross per month can be perceived as regular staff, albeit working fewer hours, but they are fully integrated into social insurance. Equal treatment with full-time workers applies. Relative to full-time employment, part-time work is characterized by a comparable extent of employment stability and a pro rata access to social protection. Part-time work is a frequently used model to reconcile work and family life for women in a situation where public childcare facilities are insufficiently developed. 
The situation is different for marginal part-time work (geringfügige Beschäftigung) below EUR 400 (BRL 920) gross per month, which has also grown strongly recently. Below this threshold, employees pay neither social security contributions nor taxes. This cost advantage, however, is partially shifted to employers in terms of lower hourly wages. Hence, this type of employment provides a second tier of "cheap labor" in some medium- to low-skilled services, in particular front-line staff in retail trade or the hospitality sector.

In Germany the use of different forms of flexible employment is not constrained by law, but staffing policies can be influenced by works councils if they exist. According to German legislation, works councils have a say regarding hiring and firing policies. Via plant-level agreements between works councils and management general principles of human resource policies can be agreed upon such as the share of agency workers or fixed-term contracts. Employees can combine different jobs as well, e.g. have a full-time job and a "Minijob" or some work both as a dependent employee and a freelancer, even in the same occupation.

Table 5: OECD Indicators of Employment Protection, 2008

\begin{tabular}{|l|l|l|}
\hline & \multicolumn{1}{|c|}{ Germany } & \multicolumn{1}{c|}{ Brazil } \\
\hline $\begin{array}{l}\text { Protection for regular } \\
\text { employment }\end{array}$ & 3.0 & 1.37 \\
\hline $\begin{array}{l}\text { Protection for fixed-term } \\
\text { contracts }\end{array}$ & 0.75 & 4.75 \\
\hline $\begin{array}{l}\text { Protection for temporary } \\
\text { agency work (Version 1) }\end{array}$ & 1.75 & 3.50 \\
\hline $\begin{array}{l}\text { Protection for collective } \\
\text { dismissals }\end{array}$ & 2.13 & 2.75 \\
\hline
\end{tabular}

Source: OECD.

Notes: Indicators measure the procedures/costs involved in dismissing individuals and the regulation for the use of fixed-term or temporary work agency contracts. The indicator ranges from 0 (very flexible) to 6 (very strict). 


\section{Brazilian dismissal protection}

Brazil has neither ratified International Labour Organization Convention 158, nor does it have a legal mechanism for dismissing employees that is comparable to that of Germany. Instead, it uses a system called the Employees' Severance Fund (Fundo de Garantia do Tempo de Serviço, FGTS) and other mechanisms to protect dismissed employees.

There are four legal mechanisms that protect for employees who are dismissed without cause: (1) a 30 day notice of termination (a period in which the employee may use two paid hours per day or seven consecutive work days to look for another job, or receive 30 days of paid leave, and during which time the employer's productivity approaches zero; (2) for dismissals not resulting from employee wrong-doing, an indemnity in the amount of $40 \%$ of the balance of the FGTS (to which the company contributes at $8 \%$ per month and during 13 months per year ${ }^{15}$; and (3) the balance accrued from deposits made on behalf of employees by employers. In other words, a dismissed employee has a period of time at their disposal, as well as financial resources, to cope with unemployment. These rules make formally registered employees an extra expense for employers.

The calculation of the cost of dismissal depends on the length of time worked in a particular firm as well as several further conditions connected with the date of dismissal and the 30 days notice. When the dismissal occurs one month before the end of the contract, the company has to pay an extra salary to the employee. If the company does not want to give 30-days' notice, it has to pay one additional month's salary. Table 6 provides an example of an employee, who makes BRL 1,000.00 (EUR 435) per month, works in the same company for three years, is dismissed close to the end of the contract and receives one month's indemnity rather than the 30-days' notice.

This example shows that a company pays about six salaries to dismiss an employee formally hired. That is one reason why many small firms take the calculated risk of being caught and penalized for not complying with the law and hire employees outside of this established regime. ${ }^{16}$ Studies show that increasing labor inspections have led to more stringent rules and increasing unemployment and informality (Almeida and Carneiro 2007, Simão 2009). Informality is decreasing in Brazil-as shown in the next sectionbut it still affects about $50 \%$ of the workforce.

\footnotetext{
${ }^{15}$ The FGTS (severance fund) is funded by contributions by employers at the rate of $8 \%$ per month of the value of employees' salaries, without any ceiling. With the advent of Complementary Law 110/2001, employers are now required to pay an additional $10 \%$ into the FGTS to finance inflation-adjustment deficits, up to $50 \%$.

${ }^{16}$ Today the fines levied for non-compliance are prohibitive and enforcing mechanisms have improved. Labor inspectors are encouraged to enforce laws, and part of their compensation is based on the number and the amount of fines applied.
} 
Table 6: Cost of dismissal of an employee in Brazil who makes BRL 1,000 per month (about EUR 435) and has worked for the company for three years

\begin{tabular}{|l|l|l|l|}
\hline Costs & Calculation & BRL & EUR \\
\hline $\begin{array}{l}\text { FGTS accumulated } \\
\text { month }\end{array}$ & $80 \times 40$ months & 3,200 & 1,391 \\
\hline $40 \%$ penalty & $0.40 \times$ update balance & 1,392 & 605 \\
\hline Subtotal & & 4,592 & 1,996 \\
\hline Previous notice (30 days) & 1 month salary & 1,000 & 435 \\
\hline Incidence 1- 13th salary & $1 / 12$ of 13th salary & 83 & 36 \\
\hline Incidence 2- Vacation & $1 / 12$ Vacation + 1/3 bonus & 111 & 48 \\
\hline Incidence 3- FGTS & FGTS s/sal. + 1/12 13 salary & 87 & 38 \\
\hline Total & & 5,873 & 2,553 \\
\hline
\end{tabular}

Notes: For clarity numbers are rounded.

Labor unions argue that the severance payment system induces turnover in Brazil. However, turnover rates are clearly related to the nature of the activity. For instance, agriculture is seasonal and sensitive to turnover, and accounts for $16 \%$ of the workforce-compared to less than $5 \%$ in developed countries. Construction is also seasonal, accounting for around $8 \%$ of the workforce. Other examples of seasonal work include temporary agency workers hired for Christmas and Easter. In addition, more than $50 \%$ of the workforce works in small shops and performs short-term services. All these factors account for a large part of the turnover rate which cannot be attributed fully to the severance pay system.

Several attempts have been made to ease the rigidity of the Brazilian labor code (CLT) in order to extend protections to informal workers as well as to protect formal employees in times of crisis. Employers were generally very supportive, but employees were divided. Those at the margin of the labor market (outsiders) tended to favor the measures, but those at the core-particularly the unionized ones (insiders)-resisted the proposed measures and pressed Congress to reject the proposition. ${ }^{17}$

\footnotetext{
17 This was the case of Bill 5.843, proposed in 2001 to reform Article 618 of the CLT. It stipulated the negotiating of vacations in three different periods of the year and the payment of the Christmas bonus in more than two installments. The bill was interpreted by the labor unions (centrais sindicais) as a
} 
Successes in Congress were later reversed in practice. An important improvement was brought by the Early Settlement Commissions (Comisssões de Conciliação Prévia) established by Law 9,958/2000 to promote direct conciliation and thus reduce the courts' workload. This law was severely attacked by trade unions and discredited by the courts and the Labor Prosecution Office (Ministério Público do Trabalho). In practice, it is a dead letter-no longer enforced but not formally done away with-revealing the political power of the judiciary community, particularly when supported by the labor unions.

\section{Flexible jobs in Brazil}

Two legal provisions offer social security and other contributions relief to companies. The first is Law 9.317/1996, which created the Programa do Simples regime and according to which small and micro-businesses are exempt from having to collect union fees and contributing to professional training, social welfare, and entrepreneurial education, which are part of the so-called Sistema S. In the first three years this program managed to formalize around 3 million employees (Cechin and Fernandes 2000).

The second legal provision offers an opportunity to self-employed people working in the informal market. Law 128/2008-also called the Individual Micro-Entrepreneur (MicroEmpreendedor Individual, MEI) - permits the informal self-employed to have the formal protections of the social security system by paying a very modest monthly contribution of about BRL 27 (EUR 12). ${ }^{18}$ The program is intended to benefit self-employed earning up to BRL 36,000 (EUR 15,650) per year. The vast majority of these people work as builders, painters, electricians, plumbers, TV repairmen, etc. The program embodies the concept of "partial protection". Since the amount withheld is not enough to provide complete social security coverage, the contributors are entitled to retirement by age, accident and incapacitation, but not by how long they have made contributions. These mechanisms are relatively new but have been well accepted by companies and employees. Estimates show that more than 1 million self-employed have been enrolled in the MEI program since 2009.

One program constraint is the limited number of occupations that are entitled to use it. Another is the legal insecurity prevailing in companies that would like to hire simple services from small entrepreneurs (under $\mathrm{MEI}$ ), as is the case in the civil construction industry. Electricians, plumbers, painters and similar professions are only needed for

\footnotetext{
"complete abolition" of labor rights. It barely passed in the lower house (Câmara dos Deputados), but its progress was interrupted in the upper house (Senado Federal) with the election of President Luiz Inacio "Lula" da Silva in 2003, who complied with insiders' demands.

${ }^{18}$ The MEI has the virtue of being portable. If a worker wishes to retire according to the period of contribution, they can pay in larger sums and retire earlier. Workers changing from self-employment to employment, or the other way around, can carry the acquired protections with them. Those participating in the MEI plan may have an employee as long as he or she earns a minimum wage. However, the introduction of the program in 2009 was frustrating as small entrepreneurs were unable to overcome the bureaucratic formalities. Several simplifications were introduced in 2010.
} 
short periods of time and for specific tasks. However, companies fear that this type of hiring will lead to the creation of an employment relationship as defined by the CLT because there is no law regulating the outsourcing of services in Brazil. Removal of such a link might accelerate the process of full integration.

Profit sharing is another form of internal flexibility. This measure was clearly established by the 1998 constitution under the name of Participation in Profits and Results (Participação nos lucrosou Resultados, PLR). The objective was to create a stimulus to internal dialogue among employees and employers, aimed at raising profit and productivity. Unlike other forms of remuneration, payments are not subject to nonwage costs. Employers and employees freely negotiate agreements that establish goals to be met and the amounts distributed. The distribution must occur in periods no less than six months. Although optional, this mechanism has been adopted by a large number of companies, and legal stand-offs are rare.

\section{Salary adjustments}

In times of difficulty the CLT has some provisions for employment adjustments. One such measure is Law 4.923/1965, which permits companies in "duly demonstrated difficulty" to cut working hours and salaries by up to $25 \%$ for a maximum of five months. This law has critical ambiguities. At some point in time, employees can claim that the company's economic difficulty is not duly demonstrated or that the remuneration and benefits of the managers have not been sufficiently reduced. Courts can invalidate the agreement and the company will be obliged to make back payments, with fines and monetary correction.

\section{Contract suspension (Layoff)}

Article 476-A of the CLT refers to a type of external numerical flexibility by allowing companies to adapt the number of employees to the economic situation. In downturns, companies can suspend contracts for a period of two to five months. The employees are placed in an intra-company training program.

However, this measure is rarely used, due to the bureaucratic complexity of obtaining approval under the requirements of Article 2 of Law 7.998/1990. Bureaucratic red tape is complex and stringent, contributing to great uncertainty on the part of the companies. The training program has to be approved by Ministry of Labor, which offers a scholarship to the workers as a sort of unemployment insurance. To do so the Ministry of Labor requires that: (a) the training courses offered by employers must demonstrate pedagogical quality, correlate with the companies' activities and be taught in suitable laboratories, seminars and workshops; (b) the Ministry shall approve the course curriculum and the conditions in which the training is to be held; and (c) in order to take part in the program, employees must report to local agencies of the Ministry of Labor, carrying copies of signed collective agreements, their social security cards or working 
papers, proof of enrollment in the course, identification, Individual Taxpayer's Number (Cadastro de Pessoa Física, CPF) and proof of enrollment in the Social Integration Program (Programa de Integração Social, PIS). ${ }^{19}$

Hours accounts (Banco de Horas)

Brazilian law offers some alternatives of internal numerical flexibility, such as hours accounts, a result of Law 9.601/1998. Employees generally tend to accept this measure, but labor unions only tolerate it during recessions.

A legal controversy persists whether this mechanism requires collective bargaining with the labor union or whether it can be arrived at by agreement between employees and employer. Many agreements have been overturned by courts, and this has led to insecurity on the part of companies, who fear that it could lead to unnecessary dismissals. An additional problem is the maximum period this measure can be used. In spite of these difficulties, however, companies have used hours accounts to cope with crises.

\section{Part-time work}

Part-time employment contracts was introduced by Medida Provisória 1.709-4/1998 and later regulated by Article 58-A of the CLT. The law offers no advantage on social costs over the hiring of permanent employees.

Part-time work cannot exceed 25 hours per week, part-time employees have the same rights as full-time workers and the hiring company has the same (proportional) expenses. However, a few benefits are not proportional, such as the transportation and food allowance (vale transporte e vale refeição). Vacation is according to the number of days worked during the year. The law, however, does not permit overtime for part-time employees. Flexible daily journeys have been used. People can work four hours in one day and eight in the following.

In most countries part-time workers are predominantly students, women and the elderly. In Brazil, however, the use of part-time in the formal segment is relatively rare. Data from CAGED for 2008 show 1.5\% of people working 25 hour per week or less. In the Brazil household survey (Pesquisa Nacional por Amostra de Domicilios, PNAD) of 2009 there were less than $2 \%$ people working 25 hours a week or less. IPEA estimates that in the formal segment there are no more than $2 \%$ in part-time. In the informal segment it is around 10\% (IPEA 2009). In Congress there is a proposition to open parttime work for $14-15$ year olds (the constitutions permits working only at 16 or older)

\footnotetext{
${ }^{19}$ As required by Labor Ministry Resolution 591/2009.
} 
Fixed-term jobs

Fixed-term contracts were established by Law 9.601/1998 for a maximum of six months, renewable up to two years. Companies are not obliged to pay for 30 days notice and the $40 \%$ penalty when ending of the contract. Furthermore, the monthly payment to FGTS was reduced from $8 \%$ to $2 \%$.

At the time the law was approved, the aim was to bring the unemployed into work. The mechanism was approved by the "excluded people" (outsiders) but less so by the unions' leaders (insiders), with the argument that the system would create two classes of workers: the protected and the unprotected. Nonetheless, the law was approved. However, in the last minute the labor union managed to introduce a disposition through which the hiring of fixed-term workers had to be approved by labor union representing the company's employees. For obvious reasons the insiders were reluctant to support the entrance of eventual "competitors". Since then negotiations have proved difficult, with some companies trying to avoid collective bargaining. But even in case of proper negotiation, courts often overturn signed contracts. As a measure of external numerical flexibility, fixed-term contracts have been used on a limited basis. In general, only large companies use them with caution in times of difficulties.

\section{Temporary agency work}

Another measure of external numerical flexibility is temporary agency work. Law 6.019/1974 permits hiring temporary employees for periods up to 90 days (renewable for an additional 90 days).

The law imposes some restrictions. The use of temporary work is permitted only in emergencies or when the company has some (temporary) extra work. The salary of temporary workers has to be the same of the companies regular workers in the same position. In this respect, the Brazilian system is somewhat different to Germany, where agency workers are treated differently in regard to remuneration. The non-wage labor costs are slightly reduced by removing the payment of severance obligation and the 30day dismissal notice. However, these expenses are included in the price of the contract established by the agencies.

In spite of these restrictions, temporary agency work is widely used-much more than fixed-term contracts. The main appeal is the availability of work when needed. In 2010 there were about 900,000 people working as temporary workers. They included mostly less-qualified personnel.

Work cooperatives are a variety of agency work. Hiring expenses are reduced because cooperative members do not belong to the permanent staff of any of the companies for which they work. They are coop affiliates rather than employees. As coop members they maintain their own protection funds (retirement, vacation, health insurance, etc.). Despite existing legal provisions, this type of external flexibility has been under a vigorous attack by authorities, trade unions, public prosecutors and court judges. The 
most commonly-cited argument is that hiring companies use this alternative to circumvent labor legislation (avoid payment of workers rights), since in most cases cooperative members ultimately differ little from those who render services as employees.

\section{Self-employment}

Around 20 million people work as self-employed in the informal labor market with no protection-mainly in low-skill occupations (e.g. street sellers, construction and small services). The Brazilian Labor Code has no provision for self-employed except for construction contractors, which are regulated by Articles 619 and 620 of the Civil Code and not the Labor Code. The contrato de empreita is a special provision for this type of work but has to be used with extreme caution because the courts may consider the employees' contractors as employees of the contracting firm. To avoid problems the objective of the contract has to be very specific.

Besides construction, the use of self-employed in other activities has been very controversial. ${ }^{20}$ Law 11.196/2005 establishes professionals who provide these types of services as entrepreneurs and are not considered employees. In 2007 Congress reinforced this principle by stating that, where doubt, these contracts cannot be overruled by the labor inspectors-only by the judges. This provision, however, was vetoed by President Lula. Therefore, judicial insecurity remains. At the discretion of labor inspectors, companies run the risk of having to incorporate self-employed professionals into their staff-together with back payments, fines and monetary correction. Self-employment is an area of great insecurity, which is why informal selfemployment so common.

\subsection{Taxes and labor cost}

Wage and non-wage labor costs in Germany are considerable. As the following table shows for manufacturing, gross wages per hours worked are only one part of the wage bill. They are complemented by different categories of non-wage labor cost, in particular payments for sickness and vacation as well as employer social contributions and occupational pension plans. Most of these non-wage labor costs have a statutory basis, but collective agreement or company-specific provisions often result in additional payments. One has to note, however, that employee social contributions and income taxes have to be deducted from employees' gross wages, so that the tax wedge between employers' labor costs and employees' net earnings is even more pronounced.

\footnotetext{
${ }^{20}$ Law, engineering information technology, public relations, human resources management, health, accounting and auditing, market and other types of research, arts and entertainment, and recreation.
} 
Table 7: Labor costs in manufacturing (\% of gross wage), 2010

\begin{tabular}{|l|c|c|c|}
\hline & West & East & Total \\
\hline Charges for hours worked & 75.1 & 77.5 & 75.4 \\
\hline Remuneration for non-working days & 17.4 & 17.2 & 17.5 \\
\hline Vacation & 10.1 & 9.8 & 10.1 \\
\hline IIIness & 3.3 & 3.5 & 3.4 \\
\hline Public holidays & 4.0 & 3.9 & 4.0 \\
\hline Special payments & 7.3 & 5.3 & 7.1 \\
\hline \multicolumn{1}{|c|}{ Wealth creation } & 0.4 & 0.3 & 0.4 \\
\hline Fixed special payments & 6.9 & 5.0 & 6.7 \\
\hline Social insurance contribution & 18.9 & 20.1 & 19.0 \\
\hline Occupational pension plan & 5.6 & 2.3 & 5.3 \\
\hline Other charges related to personnel & 4.3 & 3.9 & 4.3 \\
\hline Total & 128.8 & 126.4 & 128.6 \\
\hline Additionally: & 7.1 & & \\
\hline Share statutory labor costs & 25.9 & 27.7 & 26.0 \\
\hline $\begin{array}{l}\text { Charges related to personnel in \% of } \\
\text { charges for hours worked }\end{array}$ & 71.4 & 63.1 & 70.6 \\
\hline SourceIW Köln & & & \\
\hline
\end{tabular}

Source: IW Köln.

In Brazil, law imposes a long series of expenses to hire an employee in the formal segment. In practice, they represent more than $100 \%$ of the direct salary cost (Table 8 ) and amount to $102.43 \%$ of the nominal salary. When hiring an employee for BRL 1,000 per month (EUR 435), a company will spend BRL 2,020 (EUR 878) paying for contributions, indemnities, and worked and un-worked time (vacations, public holidays, Christmas bonus, sick leave). These are all mandatory expenses and cannot be bargained even if the parties involved might wish to negotiate them. 
Table 8: The cost of legal contracts in Brazil, hourly workers

\begin{tabular}{|c|c|}
\hline Social costs & Percentage of wages \\
\hline \multicolumn{2}{|l|}{ Group A - Social obligations } \\
\hline Social security & 20 \\
\hline Severance fund & 8 \\
\hline Educational contribution & 2.5 \\
\hline Accident contribution (average) & 2 \\
\hline Social services (SESI/SESC/SEST) & 1.5 \\
\hline Vocational training (SENAI/SENAC/SENAT) & 1 \\
\hline Entrepreneurial promotion (SEBRAE) & 0.6 \\
\hline Agrarian reform (INCRA) & 0.2 \\
\hline Subtotal A & 35.8 \\
\hline \multicolumn{2}{|l|}{ Group B - Non working time I } \\
\hline Paid weekend & 18.91 \\
\hline Vacation & 9.45 \\
\hline Vacation allowance & 3.64 \\
\hline Holidays & 4.36 \\
\hline Advance notice & 1.32 \\
\hline Sick leave & 0.55 \\
\hline Subtotal B & 38.23 \\
\hline \multicolumn{2}{|l|}{ Group C - Non working time II } \\
\hline Christmas salary & 10.91 \\
\hline Dismissal penalty $-50 \%$ of the FGTS (severance pay) & 2.94 \\
\hline Subtotal C & 13.85 \\
\hline
\end{tabular}




\begin{tabular}{lc}
\hline Group D - Cumulative incidences & \\
\hline Group A/Group B & 13.68 \\
Severance payment/Christmas salary & 0.87 \\
Subtotal D & 14.55 \\
\hline GRAND TOTAL & $\mathbf{1 0 2 . 4 3}$ \\
\hline
\end{tabular}

Source: Federal Constitution and Labor Code (CLT).

\subsection{Unemployment benefits and minimum income schemes}

In Germany, like most European welfare states, unemployment protection has two pillars: contribution-based unemployment insurance and means-tested minimum income support (Eichhorst et al. 2008, Ebbinghaus and Eichhorst 2009).

Access to unemployment insurance depends on a substantial employment record in terms of duration and remuneration. The minimum duration of employment covered by social insurance required to claim unemployment insurance benefits (Arbeitslosengeld I) is 12 months. In addition, in order to be covered by unemployment insurance employees have to earn more than EUR 400 (BRL 920) per month. Contributions are deducted from monthly gross earning up to a contribution ceiling of EUR 5,500 (BRL 12,650) per month in former West Germany and EUR 4,800 (BRL 11,040) in the former East. Higher earnings are not liable for contributions and do not lead to higher benefits. Between the minimum and maximum threshold, the level of unemployment insurance benefit is directly related to prior earnings and contributions. The unemployed receive either 60 or $67 \%$ of previous net earnings if children are present in the household. The maximum duration of benefits is between 6 to 12 months for unemployed up to the age of 50. Older unemployed can draw benefits for up to 24 months depending on employment record and age. Unemployment insurance in Germany exhibits a high degree of institutional stability, but more activation provisions have recently been introduced, and elements of early retirement have been phased out.

While contributing to unemployment insurance is mandatory for all employees in the private and public sector, access to (substantial) unemployment insurance benefits is problematic for workers with either too short employment record or low monthly earnings. This holds in particular for

- low paid temporary agency workers with either low monthly earnings or short employment spells

- fixed-term employees with short employment spells

- part-time workers with low monthly earnings 
In such cases beneficiaries of unemployment insurance benefits can also rely on additional minimum income support.

Some groups are not covered by unemployment insurance. Tenured civil servants who benefit from a lifetime employment guarantee are not integrated into the unemployment insurance regime. Civil servants with a fixed-term contract (which is typical for some academic positions) benefit from severance pay amounting to one month's salary per year of service. Most notably, marginal part-time workers are not covered by unemployment insurance. The same is true for the self-employed except for some recent founder who can continue to contribute to unemployment on a voluntary basis if they had previously been employed.

However, it should be noted that not all non-standard workers are in a "precarious" position. Some of these groups of workers benefit from relatively good chances of promotion, in particular fixed-term workers, so that repeated spells of temporary employment and unemployment are not a dominant feature. Self-employed, on the other hand, exhibit quite diverse positions in the labor market, with some of them earning little and low pay is more frequent with agency staff. Furthermore, other categories of non-standard workers, such as Minijob holders, benefit from social security from a main job or a spouse in a regular job-in fact, only full social security coverage based on other employment relationships makes these types of jobs attractive as secondary earning opportunities.

The second tier of social protection in case of unemployment is minimum income support. In contrast to some other countries, access to universal, means-tested, minimum income support (Arbeitslosengeld II) is always possible for residents of Germany who do not meet certain income thresholds due to a lack of earnings from work or the expiry of unemployment insurance benefits. In fact, the Hartz IV reform, which introduced a general minimum income benefit replacing former social assistance and unemployment assistance in 2005 , has contributed to a higher take-up rate and a lower share of undeclared poverty.

Regarding benefits and in contrast to unemployment insurance, minimum income support is not related to the level of prior earnings but means-tested. The German system provides for fixed, lump-sum, monthly cash benefits for adults and children as well as an additional allowance for housing and heating. Currently, single adults receive a net cash transfer of EUR 359 (BRL 826) per month, a couple twice $90 \%$ of this; for children minimum income support amounts to between EUR 215 (BRL 495) and 287 (BRL 660) depending on age. These benefits can be received for an unlimited period of time. Availability for placement in the labor market, willingness to take up any kind of paid work and participation in activation schemes is a statutory requirement for working-age recipients of minimum income support-otherwise benefits can be cut. Net replacement levels differ across earnings brackets and household types. Benefits received under minimum income support can come close to prior earnings for some low-paid or low-skilled workers in particular if they live in larger needy households. 
Table 9: Types of contract, dismissal protection and unemployment benefit coverage in Germany

\begin{tabular}{|c|c|c|c|}
\hline Type of job & $\begin{array}{l}\text { Coverage by dismissal } \\
\text { protection }\end{array}$ & $\begin{array}{l}\text { Coverage by } \\
\text { unemployment } \\
\text { insurance }\end{array}$ & $\begin{array}{c}\text { Coverage by } \\
\text { minimum income } \\
\text { support }\end{array}$ \\
\hline $\begin{array}{l}\text { Full-time open- } \\
\text { ended contracts }\end{array}$ & Yes & Yes & $\begin{array}{l}\text { yes, with means- } \\
\text { testing }\end{array}$ \\
\hline Part-time work & Yes & Yes & \\
\hline $\begin{array}{l}\text { Fixed-term } \\
\text { contracts }\end{array}$ & No, but stable duration & Yes & \\
\hline $\begin{array}{l}\text { Temporary agency } \\
\text { work }\end{array}$ & Yes (if open ended) & Yes & \\
\hline Self-employed & No & Voluntary & \\
\hline $\begin{array}{l}\text { Marginal part-time } \\
\text { workers }\end{array}$ & Yes (if open ended) & No & \\
\hline
\end{tabular}

The provision of social security benefits, in turn, also influences the functioning of the labor market directly. This is particularly relevant for minimum income support, which is received not only by the unemployed but also by workers below a means-tested level. Earnings up to EUR 180 (BRL 415) are disregarded, but above that level marginal taxation is quite prohibitive. So there is some incentive to combine benefit receipt with a marginal part-time job. For employers this allows for labor cheapening by shifting some part of the wage bill on to the public budget. However, upward mobility is severely hampered in such an arrangement.

Brazil

Although provided for in the Federal Constitution of 1946, unemployment insurance began only in 1986. It is fully paid by the government, with funds provided by the private sector on the basis of $1.65 \%$ of total sales. ${ }^{21}$

To claim the benefit workers have to have been employed in the formal sector for at least six months. The value depending on their average salary-varying between the

${ }^{21}$ Established by Decree-Law 2,284/1986 and regulated by Decree 92,608/1986. The Unemployment Benefit Program was created by Law 7,998/1990, and has since been altered countless times. 
level of the minimum wage, BRL 545 (EUR 237), to a maximum of BRL 1,110 (EUR 478) per month. Domestic workers are entitled to unemployment insurance only if their employers voluntarily pay into the FGTS (severance pay fund).

The length of the benefit varies from three to five months. Sixteen months are required between spells of benefit receipt. However, the period of coverage and the value of the benefit are increased during periods of crisis and high unemployment. During the crisis of 2008-09, benefits were extended to seven months but were limited to the groups most at risk.

Brazil is a unique case in which unemployment insurance expenditure increases in times of high employment rates. This is due to the growth of the number of formal employees-who are entitled to unemployment insurance-and also to a distortion in the FGTS system. Employees tend to provoke their dismissals after 12 months in order to receive the severance payment and being entitled to up to five months of unemployment insurance. Claimants are not allowed to work while receiving benefits, though many of them do so by working in the informal segment. Changes in this system have been proposed for ten years with no result (Chahad 2002).

A special type of benefit is given to those laid off as opposed to definitely dismissed. Depending upon the agreement between unions and businesses, mandatory training may be paid by the Minister of Labor (bolsa de qualificação). In practice, this mechanism is rarely used to excess bureaucracy and judicial insecurity.

People over 65 and living in a household in which the per capita income is less than $25 \%$ of the minimum wage receive one minimum wage from the Social Assistance Program (Lei Orgânica da Assistência Social, LOAS). This assistance is applicable also to the disabled.

\subsection{Active labor market policies}

\section{Germany}

Since the late 1960s Germany has had a full range of active labor market policy schemes aimed at reintegrating the unemployed while simultaneously upskilling the workforcefrom job search advice and placement assistance, hiring subsidies to employers, start-up support, direct public job creation to training schemes. Over time, active labor market policies underwent reforms, modifying existing schemes, introducing new measures and shifting the policy focus. In the 1980s and 1990s labor market schemes were also used to mask unemployment, in particular via direct job creation programs and extensive retraining schemes. Concerns about the effectiveness and the efficiency of many measures eventually triggered a major overhaul in the early and mid-2000s, when active labor market policies were both curtailed and reorganized. Activation through early reintegration into the labor market gained in importance as a major policy priority whereas long-term training lost ground (Eichhorst et al. 2008, Caliendo 2009). 


\section{Brazil}

There are three programs to promote employment: the National Employment System (Sistema Nacional de Emprego, SINE), the Employment and Income Generation Program (Programa de Geração de Emprego e Renda, Proger), and to support qualification the Worker Assistance Fund (Fundo de Amparo ao Trabalhador, FAT) (Chahad 2006). Together the chief concerns of these programs are to:

1) match potential employees to employers seeking workers (labor mediation, intermediação da mão de obra)

2) generate employment and income, achieved in part through loans

3) provide professional training

Historically, SINE has managed to place about $50 \%$ of people looking for work. In times of economic boom (like in 2010-11) the rate rises to 70\%. Data show that workers' income rises about $18 \%$ with the support of loans from PROGER. Mid-level training (provided by FAT and other programs) has provided a rise of around $12 \%$ of workers' income when compared with those with no training (Menezes 2011).

\subsection{Vocational training}

\section{Germany}

Skills creation is an important element of the German production model and of its international success. The roots of the system go back to the 19th and early 20th century, when skill-intensive industries in Germany faced increased competition by lowcost producers abroad. This encouraged many firms to try and establish a comparative advantage by higher quality and specialization, which in turn required better trained workers. This was mainly achieved by creating a co-managed, standardized and firmbased system of vocational training that provided the skills needed for qualitycompetitive goods. The corresponding strategy included the acceptance of a compressed wage structure via collective bargaining (which increased incentives train instead of poaching), the creation of internal labor markets and the voluntary coordination of employer interests (to achieve systematic and standardized training profiles) (Thelen 2004). These traditional institutions of a high-quality/high-skill equilibrium proved to be very stable and lay the foundations for what Streeck (1992) later called "diversified quality production": a novel production pattern in German manufacturing that combines the quality orientation and customization of small craft enterprises with the economies of scale of large-scale industrial production. 
At the core of vocational education in Germany is dual vocational training. Apprentices receive a general school-based education (financed by the state), combined with three or four days per week of on-the-job training paid by the firm. The schemes last for two to three years. There is a strong corporatist regulation of vocational training including binding occupational profiles as well as compulsory examinations and certified vocational degrees conferred by the responsible Chamber of Commerce or Chamber of Crafts. These chambers are self-administered public bodies with compulsory membership of all entrepreneurs active in the respective field. Standardization and comparability aim at creating industry-specific skills which allow for high mobility in occupational labor markets. As a consequence, German enterprises have long been able to train beyond short-term needs and contribute to a pool of skilled workers as a "collective good". Recently, vocational training institutes seem to have suffered a loss of their collectivist quality, as can be seen from declining training ratios (Thelen and Busemeyer 2008). However, with the emerging problem of demographic change and skill shortages, the focus of the debate now is rather on the lack of (capable) apprentices entering the system.

According to current German legislation, a master's qualification is needed to set up an independent business in 41 crafts, such as carpenters, roofers, electricians, painters, mechanics, bakers and hairdressers. Employees with a vocational degree can continue full-time training for a year or for two to three years on a part-time basis and pass an exam before the Chamber of Crafts to achieve master's status.

Figure 3 shows that almost half of the German working-age population has vocational training as their highest qualification (ISCED 3b). As some use vocational as a stepping stone to higher education, the share of people who went through the system is even higher than suggested by this number. Roughly one fifth of the working-age population is low or unskilled below upper secondary education (i.e. ISCED levels 1 and 2) (which includes those still in education). Almost $30 \%$ have a post-secondary qualification. The ISCED 4 category comprises various courses that prepares for the access to tertiary education. The academic sector is divided in universities (ISCED 5a) and universities of applied science (Fachhochschulen). The latter are typically specialized in certain topical areas and provide training with a stronger practical orientation. A similar model is the Berufsakademie, which offer academic training in cooperation with companies. Fachhochschulen, Berufsakademien and Fachschulen (which provide, among others, formal training for master craftsmen) are the major educational programs of the ISCED $5 b$ category. Approximately $1 \%$ of the German working-age population has an advanced research qualification, such as a doctorate (ISCED 6). 
Figure 3: German working-age population by highest qualification (ISCED-97), 2008

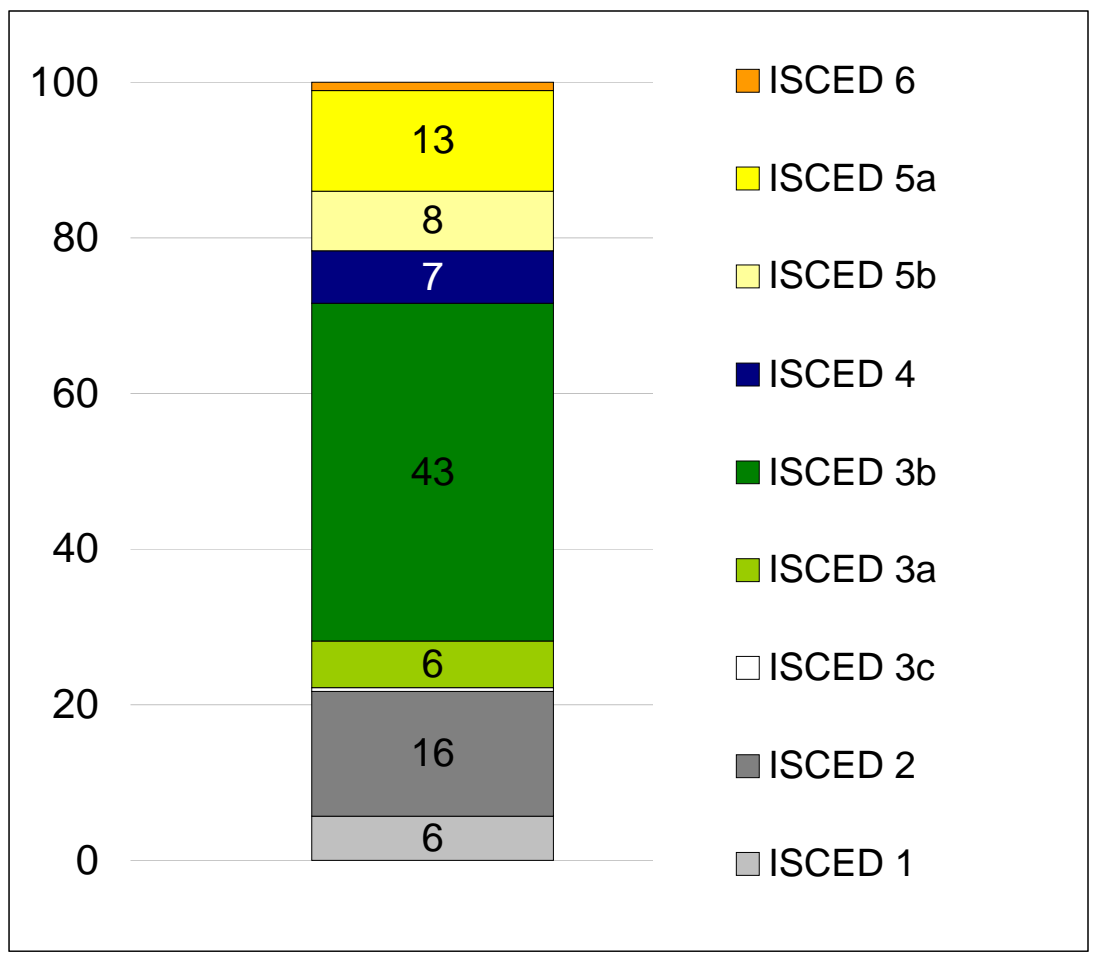

Source: Mikrozensus, 2008.

Table 10: Comparative indicators on education

\begin{tabular}{|l|l|l|}
\hline & Germany & Brazil \\
\hline $\begin{array}{l}\text { Share of working-age population below upper } \\
\text { secondary education }\end{array}$ & 15 & 59 \\
\hline $\begin{array}{l}\text { Share of working-age population with upper secondary } \\
\text { level at education }\end{array}$ & 59 & 30 \\
\hline $\begin{array}{l}\text { Share of working-age population with tertiary level of } \\
\text { education }\end{array}$ & 26 & 11 \\
\hline $\begin{array}{l}\text { PISA scores 2006 (mean male/female) } \\
\text { Science scale: } \\
\text { Mathematics scale: } \\
\text { Reading scale: }\end{array}$ & $\begin{array}{l}519 / 512 \\
513 / 494 \\
475 / 517\end{array}$ & $\begin{array}{l}395 / 386 \\
380 / 361\end{array}$ \\
\hline
\end{tabular}

Sources: OECD, Education at a Glance, 2011. 
Brazil

Brazil is facing a severe scarcity of qualified labor-which is often the case when a country grows $4.5 \%$ or more. In 2010 Brazil grew $7.5 \%$ and new investment in the areas of energy, infrastructure, and manufacturing require qualified people, which the workforce cannot provide.

The country has several institutions which can provide some sort of external functional flexibility by offering short-term training of firm-specific human capital. However, these institutions are not sufficient for the size of the workforce and the demand from the production sectors. Moreover, the educational level of the workforce is very low. The average number of years studied is 7.5 , and the education received is poor with a few exceptions. Large and medium-sized companies do all they can to maintain within their ranks qualified professionals with the knowledge base to operate the necessary machinery or work within their production systems. In times of crisis, these companies prefer to take advantage of whatever internal flexibility they have. This is particularly true for those companies that experience a high degree of external competition.

The main program in this area was the National Plan for Education (Plano Nacional de Formação Profissional, PLANFOR), which was recently changed to the National Qualification Plan (Plano Nacional de Qualificação, PNQ) - a program that has not been ranked highly by several evaluations. The number of trained people is limited and the quality is poor (Bulhões 2004). A very new program - the National Program of Access to Technical Education and Employment (Programa Nacional de Acesso ao Ensino Técnico e Emprego, Pronatec-aims to create 200 new vocational schools and train around 8 million people in various occupations until 2014-a significant challenge. The plan will integrate private and public schools in the area of vocational training.

In addition the main network of vocational schools is supported by the various organzations in the private sector and there is a strong support to train entrepreneurs and coop managers. Together with other agencies for social promotion, they form Sistema $S$, which is supported by a levy paid by the employers of the amount of $3.1 \%$ of the national payroll of the private sector. The employees make no contribution to the system. This system has an important role but programs for continual qualification are present only in few large companies. The country is suffering from a lack of more mechanisms for internal functional flexibility.

\section{Labor market dualisms in Germany and Brazil}

\subsection{Germany}

Over the last decade Germany, a traditional laggard in job creation, experienced relatively strong employment growth associated with more diversity. Although, some decline in the share and the absolute number of employed in manufacturing could be observed, it still contributes a greater share of jobs in Germany and has shown 
remarkable resilience during the most recent crisis. However, the share and absolute number of jobs in services has continued to increase significantly since the turn of the century, as Figure 4 shows (Eichhorst and Marx 2011).

Figure 4: Structure of the working age population in Germany, 1995-2009

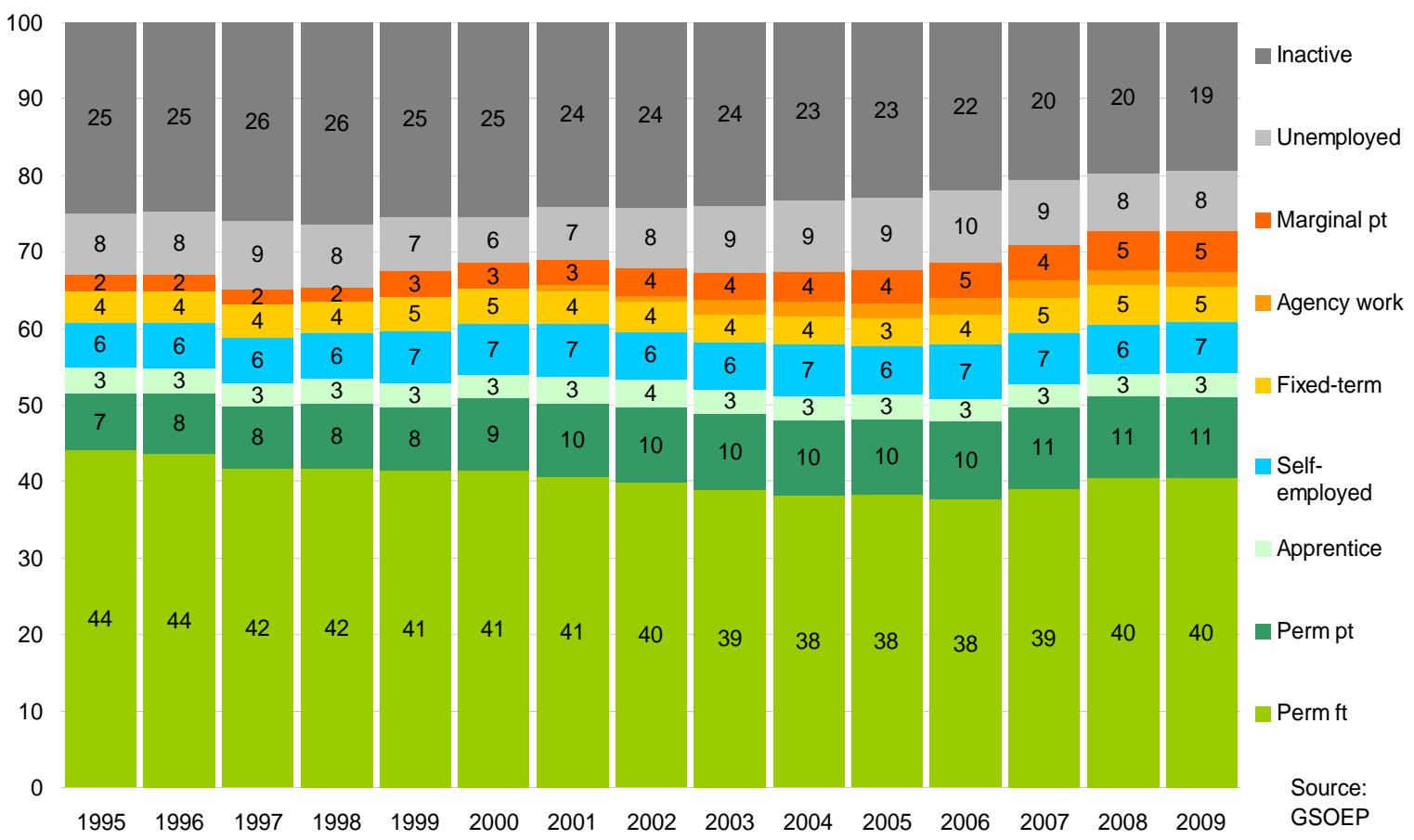

Source: GSOEP

There is also a dualization of the German labor market in terms of employment status and working conditions, with a first tier of open-ended contracts fully embedded in the dense institutional environment of the German economic model and a second tier of jobs exhibiting inferior working conditions.

Regarding the first tier-the German production model-quality production in manufacturing still forms the backbone of the German economy and continues to rely heavily on the "standard employment relationship" (Normalarbeitsverhältnis). Full-time, open-ended contracts dominate skilled occupations in manufacturing. Typically, they are fully integrated into a number of institutional provisions that limit the impact of market fluctuations and facilitate long tenure of skilled workers within a firm or sector. This holds for dismissal protection, social insurance, collective bargaining regarding wages, working time and other working conditions, and highly institutionalized codetermination of workers and trade unions via works councils and supervisory boards. This model can still be observed in many medium-sized and larger firms, mostly in manufacturing, but also in some parts of the skilled service sector and the public sector. 
Figure 5: Non-standard work and employment growth by occupations, 1995-2009

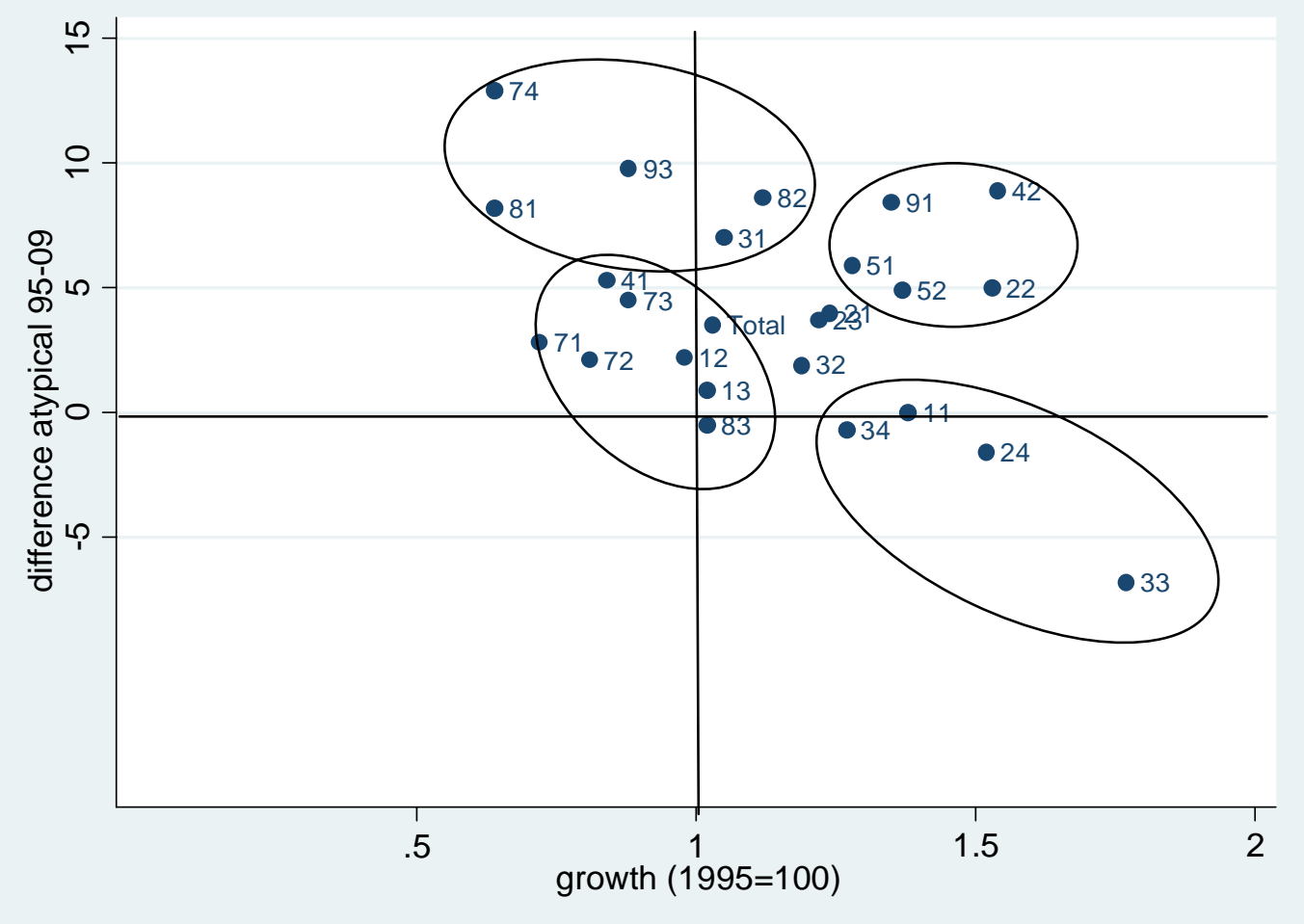

Source: GSOEP, authors' calculations.

Notes: Atypical share: fixed-term, marginal part-time, temporary agency work.

Second tier jobs are non-standard employment types concentrated in some service sector occupations, but also manufacturing. Differentiation between first tier and second tier is related to skills levels, types of occupation and sector, as well as gender. Non-standard employment is more often found in services, with more general rather than specific skills and a larger share of women in some of these occupations and jobs. Figure 5 shows the differences in employment dynamics and shares of non-standard jobs at the level of ISCO 88 2-digit occupations. We can see employment growth associated with improving working conditions in some academic occupations such as business professionals and others $(33,24,34)$. Some "traditional" manufacturing occupations, such as building, metal and machinery workers $(71,72,73)$ and wellestablished service occupations (office clerks, 41) experienced more or less stability in terms of the number of jobs and working conditions. Finally, we can see strong increases in both jobs created and the share of non-standard jobs in medium- to lowskilled personal and frontline service occupations $(42,51,52,91)$. Stagnant employment was associated with growing "precariousness" in some blue-collar manufacturing occupations $(74,81,92,93)$. 
Part-time work and marginal employment

Regarding the actual role played by different forms of non-standard work, permanent part-time work above 400 EUR (BRL 920) per month has grown significantly over the last 20 years and is probably the most "regular" form of flexible employment as it is fully integrated into social protection and exhibits a considerable degree of stability. Parttime work is mostly taken up "voluntarily" mainly by women who can better reconcile work and family duties in a country where childcare support is limited. While part-time workers may have some difficulties regarding professional promotion and suffer from some wage penalty, marginal part-time workers below 400 EUR (BRL 920) face a relatively high risk of low pay and employment below acquired qualifications. Marginal part-time work relies on a combination with other sources of income, either from social benefits such as minimum income support or pensions, spouse income or a regular first job. As wage increases or longer working time would lead to a transition beyond the 400 EUR (BRL 920) threshold implying progressive income taxation and social insurance contributions, mobility of marginal part-time workers to "regular" part-time or full-time work is quite limited (Freier and Steiner 2008).

\section{Fixed-term contracts}

The share of fixed-term employment has recently been quite stable at $13-14 \%$ of total employment. About half of all fixed-term contracts in Germany are vocational apprenticeships, which last two or three years and where transition probabilities to open-ended contracts are particularly high. In general, this also holds for contracts with limited duration in the private sector where fixed-term jobs are often used as an extended probationary period, in particular for skilled labor market entrants such as university graduates (Boockmann and Hagen 2006). The situation is completely different in the public and non-profit sector, where longer and repeated spells of fixed-term employment are concentrated. Somewhat in contrast to France, Italy or Spain, fixedterm employment cannot generally be classified as "precarious" in the German context in terms of employment stability, pay and other working conditions. Apart from the specific situation in the public sector, fixed-term employment can be seen more as a viable path of labor market entry than as a persistent vulnerable position in the labor market.

\section{Temporary agency work}

Temporary agency work is fundamentally different from fixed-term contracts in Germany with regards to mobility patterns. Mobility from agency work to regular employment is quite limited under present institutional provisions, which allow for open-ended assignments to user companies and wages significantly below those of core staff. In empirical terms most temporary agency workers are employed in low-skilled, routine activities in the manufacturing sector, such as machine operators or laborers. Not surprisingly, the share of low-paid workers is particularly high among agency staff. 
Temporary agency workers also face a higher risk of unemployment, as they take a large part of the employment risks stemming from demand fluctuations, so that many employment spells in agency work end with the assignment.

\section{Self-employment}

Self-employment, traditionally most common in craft trades and professions such as architects, journalists or medical practicioners, has recently grown. Although, government support for start-ups created by unemployed led to some growth of small firms, this was accompanied by a deregulation of the crafts sector. In creative industries such as media, design and information technology (IT), self-employment or freelance work is frequently chosen when dependent employment is not available or not sought after. Hence, in many segments of high-, medium- and low-skilled services selfemployment has become an alternative employment option. As self-employment operates outside collective agreements and most branches of social insurance labor cost are more flexible and in many cases lower so that firms tend to benefit by lower fixed costs and higher flexibility from outsourcing to the self-employed. It can result in quite dispersed earnings and income, depending on individual reputation and networks, but also from combination of earnings from self-employment with other sources and jobs. More traditional professions such as lawyers, architects or medical professionals benefit from sectoral social protection schemes and stricter access regulation.

\section{Low pay}

The share of low-paid work has also grown in Germany. While it is true that some forms of non-standard employment such as agency work or marginal part-time employment exhibit a higher risk of low pay, low wages can also be found in open-ended full-time employment relationships, in particular in occupations requiring few skills. Empirical studies have shown that sectors with low bargaining coverage are more likely to have higher shares of low-paid workers in Germany (Dustmann et al. 2009). In contrast to the first tier employment segment, a low-skill/low-pay equilibrium has emerged in some occupations. Government-sponsored labor cheapening has played a role here-in particular by combining low earnings with minimum income support and lower taxes and contributions on marginal part-time work. Upward mobility is greatest among younger, better skilled and full-time workers on low pay (Schank et al. 2009).

\subsection{Brazil: Non-standard contracts and informality}

The high cost of legal expenses has led to widespread informality, forming a dual labor market. In the more advanced segment, skilled labor predominates, with high levels of productivity and broad protection for workers. This is true in the cutting-edge industries of aircraft, automobiles, petrochemicals, communications, IT, the financial sector, and public and private utilities such as energy and telecommunications. Workers here are 
formally hired and enjoy both statutory and negotiated protections. This is the world of the insiders-enjoying the highest salaries and the most generous benefits.

Alongside the formalized labor market are sectors in which basic protections are nonexistent or severely limited, where salaries are low, working conditions are poor, and job insecurity is pervasive. These include the bulk of the primary sector workforce (agriculture, livestock, and fisheries), civil construction, low-skilled services (domestic help, delivery services and general personal services), the vast majority of those who work in small and "micro" businesses, and the self-employed. There is little worker protection in this informal labor market and wages are low. This is the world of the outsiders and comprises of nearly $50 \%$ of the workforce. Although we recognize a continuum between completely protected and unprotected segments, we focus on the two extreme categories in order to characterize formal and informal areas.

There are certain links between the two segments. Salaries in the informal sector (especially at the lower paying end) tend to rise whenever the minimum wage in the formal sector increases, although the average salary is still $63 \%$ lower. The informal sector is also becoming more heterogeneous with the entrance of more sophisticated professionals who do not want to be or cannot be formally registered as employees. These include consultants, IT technicians, private teachers, advertising professionals and those who provide services such as building maintenance.

Although the number is decreasing, 50 million people work informally-about $45 \%$ of the workforce. These workers face high-risk situations (accidents and disease), which in most cases are covered by social welfare agencies. ${ }^{22}$ In addition, there is a realm of a semi-informality, in which employees are registered but their wages are understated so employers can save on costs. It is difficult to estimate the magnitude of this type of arrangement. Furthermore, $90 \%$ of self-employed do not contribute to social security and, therefore, are not eligible for any kind of benefit (sick leave, retirement, pension).

What is the profile of informal workers? The PNAD shows that the people most affected by informality are older workers and women. ${ }^{23}$ Young people, on the other hand, are more affected by unemployment. Among people aged 16-24, unemployment is almost three times higher than the overall rate ${ }^{24}: 17.7 \%$ and $8.3 \%$, respectively. The problem is more severe among women.

Unemployment is higher at the mid-ranges of educational level and lower at the two extremes. Except for those jobs that still require manual labor, the new occupations require professionals with education of good quality beyond the intermediate level

\footnotetext{
${ }^{22}$ For example, when the poorest workers reach 65 years of age, they receive one minimum wage per month, as guaranteed by the Organic Social Welfare Law (Lei Orgânica da Assistência Social-LOAS), Law no 8,742/1993.

${ }^{23}$ Almost $73 \%$ of men aged 60 and over had no social security protections. For women of this age group the share is $88 \%$. Among those aged $25-35$, informality occurred in $37 \%$ of men and $40 \%$ of women.

${ }^{24}$ This is a universal phenomenon, but it is disturbing to note that the difference increased between 2002 and 2009 due to a drop in overall unemployment.
} 
(Baltar 2010). Demand seems to have increased more than the quality of the education available.

Education is higher among formal workers and lower among informal ones. In 2009 80\% of those with no schooling worked informally. The same occurs with the vast majority of those with little schooling (one to three years). Participation in the informal market begins to fall at eight years of schooling, but it falls most significantly at 11 years (intermediate level). Even so, it is important to remember that nearly $30 \%$ of workers at this level of schooling are unprotected. ${ }^{25}$

What accounts for reduced informality in Brazil? The end result seems to be a combination of accelerated economic growth with the formalization of companies themselves, ${ }^{26}$ the improvement in education and the increasing demand for employment protection on the part of workers. Greater government oversight is another factor. The easing of credit, including loans that are paid back through paycheck deductions seems to count. ${ }^{27}$ Finally, a few changes in the labor laws such as the regulation of temporary agency work, hours accounts, layoff and profit sharing have been given as reasons (Neri and Fontes 2010).

Why do high levels of informality persist? Bureaucracy and high hiring expenses play an important role. Much time must be dedicated to filling out paperwork for the Ministries of Labor and social security, while much effort must be applied to understanding and complying with the myriad rules governing health, safety and the environment, as well as quotas for apprenticed minors and the disabled. ${ }^{28}$ Regarding hiring expenses, large companies at the top of the pyramid may be able to afford them (although they affect their competitiveness) but most of the small and micro enterprises at the base cannot. This is the niche of most informality in the urban areas along with small properties in the agricultural sector.

Informality can be considered as a primitive form of flexibilization in Brazil because the informal workers enjoy no protection, the State collects no contribution and employers have no legal security. In Germany, flexibilization occurs at the margin of the labor market but under reasonable safety nets in which the three parties are protected.

\footnotetext{
${ }^{25}$ The nearly $16 \%$ of high-skilled informal workers include, in large part, self-employed who do not wish to contribute to social security.

${ }^{26}$ Several factors contributed to the formalization of companies, e.g. contracts with government agencies or with larger companies, export activity, the expansion of credit, and greater government oversight.

${ }^{27}$ This is a subsidized line of credit offered by banks with lower-than-market interest rates. Payments are withheld from the paycheck of the borrower and passed along to the creditor bank.

${ }^{28}$ Law $10,097 / 2000$ and 7,853/1989 as well as accompanying enabling legislation.
} 


\section{Coping with the crisis}

\subsection{The use of flexible mechanisms in Germany}

After a difficult period between 2001 and 2005, the German economy experienced a phase of economic revival from the mid-2000s up to the crisis in late 2008. Unemployment declined significantly during these years. Germany was heavily affected by the steep decline in international trade due to the global crisis. This external shock led to a significant fall in orders and exports, particularly in core areas of the German production model, such as machinery and automobile manufacturing. However, despite its vulnerability due to dependency on exports and the associated GDP decline of $5 \%$ in 2009, unemployment basically remained stable, as did the total employment rate. How can we explain this surprisingly resilient labor market performance (see Table 11)?

Table 11: The different components of labor market reaction in Germany

\begin{tabular}{|l|c|c|c|c|}
\hline & 2008 & 2009 & 2010 & $\begin{array}{c}2011 \\
\text { (medium IAB } \\
\text { scenario) }\end{array}$ \\
\hline Real GDP, \% & +1.0 & -4.7 & +3.6 & +2.4 \\
\hline Hours worked, \% & +1.2 & -3.1 & +2.9 & +1.7 \\
\hline - In full-time & +1.0 & -4.0 & +2.8 & +1.7 \\
\hline - In part-time & +2.6 & +1.2 & +3.4 & +1.8 \\
\hline Total employment, \% & +1.4 & -0.1 & +0.5 & +0.9 \\
\hline Total employment, 1,000 & 40,216 & 40,171 & 40,438 & 40,841 \\
\hline $\begin{array}{l}\text { Employees covered by social } \\
\text { insurance, \% }\end{array}$ & +2.1 & 0.0 & +1.2 & +1.6 \\
\hline Unemployment, 1,000 & 3,268 & 3,414 & 3,238 & 2,927 \\
\hline Unemployment rate, \% & 7.8 & 8.1 & 7.7 & 7.0 \\
\hline
\end{tabular}

Source: Fuchs et al. (2011). 
On the one hand, it is a consequence of persistent growth in major parts of the private and public service sector, which could offset limited losses in export-oriented sectors such as manufacturing and logistics. On the other hand, the relative success of the German story is explained by the fact that the core labor market of skilled workers in manufacturing is covered by strong legal dismissal protection. Hence, layoffs are a rather expensive form of short-term adjustment and many firms developed an elaborate arrangement of internal flexibility (Fuchs et al. 2010a, 2010b, Möller 2010). Three elements are crucial for this strategy:

1. Internal flexibility: flexibility on the enterprise level (comprising in particular working-time arrangements and to a lesser extent also remuneration) is comparatively well developed in Germany (Eichhorst and Marx 2011). It has increased considerably over the past 20 years, also as a lesson from previous crises in which layoffs led to the loss of skilled labor. Thus, internal flexibility is particularly attractive for employers in manufacturing industries with high and specific skills that are difficult to replace. Internal flexibility was enhanced by developments in the framework of collective bargaining, but also by initiatives at the enterprise level. Most importantly, working time can be adjusted flexibly via working-time accounts. In these accounts, working hours can be accumulated over a relatively long time period. As this allows companies to react to changes in demand without hiring and firing, it favors a stability-oriented personnel policy and compensates for the effects of limited external flexibility (i.e. strict dismissal protection). In fact, the economic crisis was preceded by a boom period in German manufacturing, so that many working-time accounts showed large surpluses which could be balanced after demand collapsed. Surpluses in working-time accounts and overtime declined significantly in the crises and therefore made an important contribution to employment stability. Whilst employment was virtually unchanged from late 2008 to late 2009, the total volume of hours worked declined by about 3 per cent. At the same time, the social partners made a contribution to managing the crisis. Previously, German collective bargaining was increasingly decentralized via "opening clauses". Such clauses allow for plant-level deviations from collective agreements, also in terms of remuneration. This was used in the current crisis by works councils to trade wage concessions against employment stability. Thus, many companies were allowed to adjust agreed wages or postpone wage increases. Moreover, the unions took a very pragmatic stance in sectoral wage bargaining and accepted real wage cuts in manufacturing.

2. The concentration of redundancies in the marginal workforce: for over five years manufacturing employers have increasingly relied on temporary agency staff to establish a flexible segment of the workforce, which can be swiftly adjusted under uncertain economic prospects. This is a consequence of various steps of de-regulation that made agency work a particularly cheap and flexible type of employment in Germany. There have not yet been any limits for the length of assignments in user companies and agency workers can receive wages 
significantly below the rate agreed in collective agreements. So while tasks that require high firm-specific skills are still mainly performed by permanent workers with long tenure, agency workers are extensively used for routine tasks. This "dual" model-even if highly questionable in normative terms-turned out to be very efficient for many employers. When the crisis began, employers started to drastically reduce the use of agency workers by about 300,000. Thus, employment decline could basically be limited to this category of workers. On a smaller scale, the same is true for fixed-term contracts, of which many were renewed in the crisis (Hohendanner 2010).

3. Heavy reliance on a public short-time work allowance: subsidization of reduced working hours has long been embodied in the institutional measures of the German unemployment insurance and active labor market policy system. For example, it played a major role in attempts to manage structural change in the former East Germany after reunification. Afterwards it did not play a major role, except for specific sectors such as construction. However, in the current crisis it was of paramount importance. In 20091.1 million people worked short-time (about 350,000 full-time equivalents), which meant the scheme made a major contribution to keep open unemployment low. The OECD estimate of about 220,000 jobs saved suggests deadweight losses of about one third (OECD 2010). The major reason for this was that the scheme was substantially modified to cope with the crisis. As most changes are temporary, the effects should be partly seen as consequences of discretionary interventions rather than of automatic stabilization. The scheme was modified in three aspects: (i) the maximum duration for which hours not worked are reimbursed by the unemployment fund (at the regular replacement rate applicable in case of unemployment) was increased from 6 to 24 months for 2009 (18 months in 2010); (ii) for cases of short-time work arising in 2009 and 2010, employers are exempt from social security contributions for hours not worked: regarding employee contributions from the first day of short-time work, regarding employer contributions from the seventh month of reduced working time (or earlier in case of employer-provided training); and (iii) administrative requirements for firms entering this scheme were simplified considerably.

In the German case, automatic stabilization was mainly achieved through short-time work and working-time adjustment. A recent estimate for the years 2008 and 2009 suggests that about 25 per cent of all work-time reduction was achieved by short-time work, while working time based on collective agreements contributed 40 per cent and less paid overtime as well as hours averaging in working time accounts 20 per cent (Bach et al. 2009). There was no heavy inflow into the relatively generous and universal benefit system which would have had an additional stabilizing effect on the economy. Given the robustness of the German labor market, it comes as no surprise that discretionary action in terms of labor market and social policy was rather limited. Apart from the increased generosity of the short-time work scheme and eased access of agency workers to short-time work, discretionary policies put only some emphasis on 
strengthening the activation strategy directed towards the unemployed by announcing to hire additional staff for job placement agencies. Otherwise, activation policies continued as before.

Given the abrupt character of the crisis and the uncertainty of its duration, employers have been reluctant to dismiss skilled staff as long as partial unemployment is feasible and a recovery is expected. The German fiscal stimulus package has so far seemed to have had only a limited impact in the labor market (except for the expansion of the partial unemployment scheme). Further measures tried to stabilize consumer confidence, such as a marginal cut in income taxes and social security contributions, and a "cash for clunkers" scheme implemented in 2009. Most recent figures on the development of GDP and exports show strong signs of recovery associated with further employment stability and new hirings occurring both in the temporary agency sector and in skills-intensive core manufacturing activities. Hence, German labor market performance in 2009 and 2010 was better than in earlier forecasts. Working-time flexibility and complementary short-time work allowances have helped bridge the slump in manufacturing without endangering the skilled core workforce.

Most recent policy action is addressing the issue of an increased need for budget consolidation. The government adopted a package implying some marginal cuts in social benefits, and it was decided in 2010 to prolong the expanded short-time work scheme until early 2012, but again the exceptional and time-limited character of the current provisions was restated.

\subsection{The use of flexible mechanisms in Brazil}

The Brazilian economy has also been growing lately. In 2010 GDP increased 7.5\%. However, the 2008-09 crisis brought severe problems. The year 2008 had begun well and in September 2 million jobs were created. The final three months, however, turned disastrous as domestic and international credit disappeared.

The crisis was concentrated mainly in the mining industry (which is highly dependent on exportation), manufacturing, and building. Within manufacturing, demand fell off most sharply in the areas of metallurgy, mechanical and electrical materials, vehicles, footwear, and industrial food and beverages. The south-east-comprising the states of São Paulo, Rio de Janeiro, Minas Gerais and Espírito Santo-was the most affected.

Automotive production fell from 300,000 units in October of 2008 to 97,000 in December, with sales falling sharply. In December 650,000 jobs were lost-273,000 in the industrial sector alone. In January 2009, car sales all but came to a halt. Manufacturing capacity utilization fell from $84 \%$ to $77 \%$ (rebounding to $83 \%$ only in September of 2009). In the same month terminations exceeded 100,000 . By July the 
labor market had essentially stalled. ${ }^{29}$ Industrial GDP shrunk to -0.2\% compared to 2008. The gloomy job market of December 2008 followed on to January, with an additional 101,000 jobs lost $-55,000$ in manufacturing. In industry alone more than 400,000 jobs were lost from December 2008 to July the following year. However, the country's GDP still grew about $5 \%$.

The federal government acted quickly, applying stimulus measures to revive the economy $^{30}$, implementing a series of measures to bolster credit and stimulate production. One of the most aggressive programs was the construction of subsidized low-income housing, which received some BRL 98.17 billion (EUR 42.86 billion) of investment between 2009 and 2010. Other contributing factors came from the price boost in several commodities, particularly mineral, soy, sugar, cotton and meat. The combined government measures and price factors cushioned the impact of the crisis and prevented unemployment rising. It is estimated that without these measures, GDP in 2009 would have been -2 or $-3 \%$ rather than $-0.2 \%$, and that unemployment would have gone beyond $10 \%$. In fact, signs of recovery began to show early in the second quarter of 2009, although the industrial sector took a longer time to recover the jobs. While goods and services generated 800,000 formal jobs throughout 2009, industry and manufacturing generated only 11,000 new positions. Overcoming 2009, Brazil entered in 2010 with good perspectives. The situation was back to normal and promised to break all records, which was what happened. In that year around 2.5 million jobs were created in the formal segment and real salaries increased by $4.2 \%$.

How did the industrial sector behave during the crisis? Two patterns were observed. Many large companies simply fired employees at the first signs of danger, but there were firms which used as much as possible the available flexible measures. The most used measure was the working-time arrangements and hours accounts. This was particularly true in companies with high and specific skills which are difficult to replace. Part-time and temporary work as well as fixed-term contracts were relatively rare. The main problem for the companies was to keep the crucial manpower for times of recovery. Layoff was used by a few firms.

\footnotetext{
${ }^{29}$ In these months few formal jobs were created: 9,000 in February, 35,000 in March, 106,000 in April; 132,000 in May, 119,000 in June and 138,000 in July. Only in August did the number of new jobs exceed 200,000 .

${ }^{30}$ The following stand out among the chief measures taken: (1) reduction in interest rates and in the amount banks were required to maintain on deposit with the central bank; (2) expansion of credit by the state-owned banks for both production and consumption; (3) stimulus for key sectors by means of an exemption (or reduction) in taxes (automobiles, motorcycles, household appliances, and building materials); (4) the unveiling of a large low-income housing initiative (My House, My Life, Minha Casa, Minha Vida); (5) the expansion of investment by state-owned banks in state-held companies (such as Petrobrás); (6) stepped-up investment in infrastructure projects (Accelerated Growth Program, Programa de Aceleração do Crescimento, PAC).
} 
Table 12: The different components of labor market reaction in Brazil

\begin{tabular}{|c|c|c|c|c|}
\hline Item & 2008 & 2009 & 2010 & Observation/Sources \\
\hline Real GDP (change in \%) & +5.2 & 0.6 & +7.5 & PIB Annual variation. IBGE \\
\hline $\begin{array}{l}\text { Total hours worked } \\
\text { (change in \%). }\end{array}$ & +4.5 & -7.4 & +7.1 & $\begin{array}{l}\text { Index-unseasonal. Industry only. } \\
\mathrm{CNI}\end{array}$ \\
\hline $\begin{array}{l}\text { Hourly productivity } \\
\text { (change in \%) }\end{array}$ & -0.3 & +3.7 & +2.4 & $\begin{array}{l}\text { Index-unseasonal sales/index } \\
\text { unseasonal hours.-means-CNI }\end{array}$ \\
\hline $\begin{array}{l}\text { Hours Worked full-time } \\
\text { Formal }+\quad \text { informal } \\
\text { (change in \%) }\end{array}$ & -0.5 & -0.3 & n.a. & $\begin{array}{l}\text { Average worked hours week > or } \\
=30 \text { hours per week. PNAD } 2007 \\
2009\end{array}$ \\
\hline $\begin{array}{l}\text { Short time workers. } \\
\text { Formal }(1,000 \mathrm{~s})\end{array}$ & 4161 & 4336 & n.a. & $\begin{array}{l}\text { RAIS } 2008 / 2009 \text {. Up to } 30 \text { hours } \\
\text { per week. Employees only }\end{array}$ \\
\hline $\begin{array}{l}\text { Total employment. } \\
\text { Formal }(1,000 \mathrm{~s})\end{array}$ & 39442 & 41208 & 44068 & $\begin{array}{l}\text { RAIS 2008/2009 }-\quad \text { Total } \\
\text { employed in Dec. } 31\end{array}$ \\
\hline $\begin{array}{l}\text { Total employment } \\
\text { (change in \%) }\end{array}$ & +4.8 & +4.5 & n.a. & $\begin{array}{l}\text { RAIS 2008/2009 }-\quad \text { Total } \\
\text { employed in Dec. } 31\end{array}$ \\
\hline $\begin{array}{l}\text { Unemployment rate. } \\
\text { Formal + informal }\end{array}$ & 7.9 & 8.1 & 6.7 & $\begin{array}{l}\text { Unemployment rate } \\
\text { Metropolitan areas. IBGE. }\end{array}$ \\
\hline n.a. $=$ & & & & \\
\hline
\end{tabular}

In the first group, companies fired the temporary employees first and next some of the core business employees. The aircraft manufacturer Embraer, for example, eliminated 4,270 positions in a single stroke. Electrolux (electrical appliance) dismissed 3,000.

In the second group, companies initially placed their employees on "collective vacations" (or temporary plant closures) or offered them paid leaves of absence. Upon the workers' return, they sought to reduce working time, reaching agreements to use employees' leave hours or to reduce working hours while cutting salaries. If the situation did not improve, some companies made use of the temporarily suspension of contracts-temporary layoff. In doing so, these companies managed to preserve their most valuable asset-human capital-and embarked on the second quarter of 2009 well positioned to quickly resume and normalize production. Now the employment problem became inverted, with the development of severe shortages of qualified labor. 


\section{Case Studies}

Although, public opinion surveys revealed that $50 \%$ of Brazilians were in favor of flexible measures to preserve jobs and only 39\% were opposed (CNT-SENSUS, 2009). There were many sources of resistance. Government officials, including the Minister of Labor, judges and attorneys specializing in labor issues, as well as labor prosecutors tend to openly express many reservations. ${ }^{31}$ Where companies tried to negotiate cuts in time and salary to cope with the 2008-09 crisis, the prosecutors for labor affairs were opposed, even after collective bargaining. The opposition came from the obscure message implanted in the laws themselves. As mentioned before, Law 4.923/1965 stipulates that time and remuneration cuts are to be used only where economic difficulty has been demonstrated, but which may not be accepted by the courts later on. This generates much insecurity in management, which means the measure is seldom used.

Uncertainties such as these lead many companies to opt for direct termination of their employees. That is why flexibilization measures are adopted by few companies and with extreme caution.

Within strict limits, between December of 2008 and June of 2009, there was a slight intensification in the use of flexible measures to save companies from bankruptcy and to preserve jobs. In these companies, the final result was positive, both for the employees and for the companies. But, according to many employers, what really saved the companies and the jobs was the short length of the crisis.

The following paragraphs report four cases in which flexible measures were used with different intensity.

\subsection{Company 1 - Extreme resistance, little flexibility}

In November of 2008 the inventory of this company was very high. Production was drastically reduced and an excess in workers formed. The company attempted to use hours accounts but the union leadership rejected it. The company then tried to suspend labor contracts (temporary layoff), putting the employees on paid training. The labor union also opposed this. The leaders alleged that to agree to such measures would "kill" their prestige among the affiliated members. They were more concerned with their own image than with the job preservation for the employees. This self-serving ideology is common in Brazilian unionism.

The union leaders knew that without the adoption of flexible measures, mass termination would be unavoidable. But the disaster would result from a solitary decision

\footnotetext{
${ }^{31}$ The Office of the Public Prosecutor for Labor Affairs of the 2nd Region (São Paulo), on 02/03/2009, published a position paper warning businesses that agreements resulting in the reduction of work hours and salary that were not in compliance with the terms of Law 4,923/1965 would result in action being taken in court for the purpose of annulling such agreements.
} 
of the company's management which would give them a chance to mobilize the employees against the act, nurturing their reputation as brave leaders.

With no solution, the company granted a paid collective vacation from mid December to the end of January of 2009. At the same time, the company started the dismissal program that, by the end of May, reached about 5,000 workers. After the recovery, the company decided to outsource several of its services to external firms. A small number of the dismissed workers were hired by these companies. Another part was re-hired beginning September of 2009 when production and sales began to return to normal.

In sum, this company emerged from the crisis with a smaller and different workforce in which many activities were outsourced and were carried out by other companies. Many workers lost good jobs. This case shows that the anti-business culture of the labor union was greater than the inflexibility of the laws and forced the company to take radical measures.

\subsection{Company 2 - Flexibility at very high price}

This company also was holding a high volume of inventory in December of 2008 and was facing a severe liquidity problem. During that month, orders disappeared and the situation became alarming. The company had to close its main factory for two weeks, putting thousands of employees on paid vacation, including the administration and executive staff.

Partial activities were resumed in January of 2009. An hours account agreement was in force and was used with no resistance. Production employees worked fewer hours and the company accumulated a large volume of credits. However, the resistance came in relation to the use of these credits because according to a previous collective bargaining agreement employees were supposed to pay their debits working only 30 minutes per day. The company did not succeeded in convincing the union leaders to change this clause in time of crisis. In short, hours compensation took years to be completed. Flexibility was limited and the end result was very expensive to the company which, again, was saved because the crisis was short.

Sales have since remained stalled. In February 2009 the company promoted a voluntary separation plan (PDV) with no response. The company granted paid leave to the production employees, beginning with temporary workers and soon extending it to most of the regular workers. From this point on many paid leaves were granted.

In June 2009 the situation became more alarming. The company had no choice but to dismiss a large part of its personnel, beginning with a group of retired people who were employed in times of need. Since they had a considerable experience and were performing at a high level, the company considered the dismissal as an unfortunate loss of human capital. On the other hand, the labor union requested, and the company agreed, that paid leaves of absence should be granted to temporary employees who were young, and had been with the company for approximately one year. 
Sales began to rebound in August of 2009, at which time production returned to almost its normal level. From this point forward, the process became inverted. New employees were hired, new shifts were established, and workers were paid to perform overtime. In 2010 the company began operating at full capacity and made moves toward expanding.

In sum, the company made use of the few flexible measures except layoff. ${ }^{32}$ The use of reduced work hours and salaries was likewise rejected due to the risks of an unfavorable interpretation of Law 4,923/1965, according to which the implementation of such a measure requires adequate proof of the company's economic difficulties.

Despite the positive relationship between the employer and the labor union, the crisis was met with enormous sacrifices on the part of the company and hundreds of employees who, for lack of greater flexibility, had to be dismissed.

\subsection{Company 3 - Flexibility at affordable price}

For this company, signs of crisis emerged in November and December 2008. In those months sales fell nearly to zero. Due to the critical situation, the company had to cut about $25 \%$ of its workforce. The company had previously eliminated all overtime and not renewed contracts for fixed-term workers, affecting 800 employees. Leave balances had also been exhausted as much as possible.

Having explored all these measures, and with no relief in sight, the company suspended the production and placed all production employees on unscheduled collective vacation. The administrative area continued to function as usual. Things would begin to move only in January 2009 after the implementation of the government stimulus program. Yet sales remained far below what was normal. The company began to analyze the pros and cons of the available flexible measure to relieve costs and it decided to use the temporary layoff. The idea was proposed to its employees via their union and well explained. The suspension of labor contracts would be done under the terms of Provisional Regulations 1,726 and 1,709-4 and of article 476-A of CLT. The initial reaction of the union leaders was negative-finally the unions not only accepted but also defended the measure before the local bureau of the Ministry of Labor.

The company's attorneys' initial reaction was similar to that of the unions. However, following great efforts of persuasion, they accepted and helped formulate the solution, taking care to act in full compliance with the law. Based on this decision, the suspension of labor contracts of $25 \%$ of the workforce was negotiated for five months (the limit permitted by law), without impacting vacation time or the thirteenth salary. In addition, a 140-hour training program and the use of a fund provided by the Ministry of Labor for

\footnotetext{
${ }^{32}$ The use of layoffs was contemplated and ultimately rejected due to the legal vagaries involved, and the opposition of the labor union, in addition to the operational complexity of applying this to thousands of employees. The bureaucratic requirements of the Ministry of Labor make it practically impossible to lay off thousands of employees.
} 
this purpose-as well as an additional payment by the company-brought employees' take home pay up to the required level, all the while preserving their net monthly salaries and the 8\% FGTS (Employees' Severance Fund) contribution. The complex bureaucracy was overcome. The training program began mid-January and the workers stayed there until March when sales began to rebound. About $15 \%$ of the trained workers decided to leave the company and were replaced by new employees. In June 2009 the company returned to normal.

Implementing temporary layoffs in Brazil involves numerous bureaucratic hurdles and demands a heavy investment in time and personnel resources, which was costly for the company. However, the company's action was less expensive than a mass dismissal and subsequent re-hiring and training. Here too, the company does not know what it would have done had the crisis lasted six more months.

\subsection{Company 4 - mild impact and no flexibility}

This company was less affected by the crisis compared to the previous cases. Different flexible solutions were used in different plants. In factory 1 , product inventory was high and sales fell sharply in November 2008 and production needed to be curtailed. The company tried to reduce working hours while cutting salaries and leave balances. Both of these proposals were rejected by the labor union. The company was therefore obliged to put employees on unscheduled collective vacation for 30 days. Having exhausted its vacation period, without a sales recovery, the company had no choice but to shut down the factory for several days. The company accumulated seven days which were worked throughout 2009 but were "paid back" only in the beginning of 2010.

In factory 2 the situation was different. Sales had a slight fall-off during the crisis. Overtime was suspended, fixed-term contracts (about $4 \%$ of the workforce) were cancelled and two complete shut-downs were carried out for nine days in December 2008. In addition, ten days of collective vacation time were granted. Due to union resistance, the Voluntary Separation Plan (Programa de Desligamento Voluntário, PDV) was made available to 350 working retirees. Normal conditions came back in February 2009.

In factory 3 employees had been working many hours of overtime throughout 2008. In November, inventory was very high and sales dropped off significantly and overtime was suspended. Employees in the inactive divisions were granted vacation during December and there was a complete seven-day shutdown. A leave balance system was in force as a result of previous collective bargaining. The days used to be "paid for" on every other Saturday. This system, however, made the pay period to surpass the legal 12 months maximum time. The company would like to extend the remuneration period beyond 12 months - the law does not permit.

In factory 4 the company granted 19 collective vacation days in January and February and shut down the plant for four days in January. This factory employed special teams 
that worked 20 hours over the weekends, providing the company with greater flexibility. In February sales resumed, as did production.

In conclusion, the effects of the crisis were relatively mild for this company. It did not use layoffs or reduction in working hours and salaries. More frequent was the closure of factories at the most critical moments, and remuneration for unworked days throughout the year, as well as the granting of unscheduled collective vacations. Human resources managers, however, believe that if the crisis had lasted longer, the measures adopted would have been insufficient, and a high resistance was present to adopt the legally-permitted flexibility measures. The existing measures were also considered too rigid to meet the needs of the company.

The flexible mechanisms-with three exceptions (hours account, agency work, and outsourcing)-are rarely used in Brazil. The main reason is related to the judicial insecurity. Labor courts can void collective and individual agreements. Employers are afraid of being penalized after two to three years, with back payments, fines and monetary correction. Laws and labor courts are much stronger than the parties' free will. In addition, many labor laws are obscure and generate uncertainty. Finally, labor unions are generally against the use of flexible measures.

During 2010-11, with the return to full employment (unemployment has been around $6 \%$ ) and with the persistent shortage in manpower, the unions again declared the flexibilization of labor laws unnecessary. The political climate is not favorable for approving new flexible measures, or even for correcting the flaws in those currently in place.

\section{A comparative assessment and policy conclusions}

\section{Industrial relations}

Brazil and Germany have industrial relations systems, welfare states and arrangements of labor market regulation that are quite different. Regarding industrial relations, which are at the core of this study, Germany developed solid collective bargaining mechanisms over time, and employers and trade unions were able to adjust these mechanisms to match changing economic conditions. In Germany a dense institutional network organizes the different dimensions of labor relations-collective bargaining, the codetermination system at the company level and the workers councils at the plant levelall of them intermediated by labor unions and management associations. Today German industrial relations support several mechanisms to cope with the needs of companies in the areas of innovations and competitiveness and the needs of workers in the areas of employment and qualification. Collective agreements are respected by parties and operate without interference by the state. Negotiations on-going at all levels and mutual understanding among employees and employers and their capacity to resolve 
conflicts in a constructive way is high. This system can be seen as a major pillar of Germany's post-war economic success and a helpful aid to deal with crises.

In the case of Brazil, most mechanisms were defined by law in the 1940s and little space was reserved for collective bargaining. Government plays a significant role and courts often interfere. The rigidity of the system is one of the major determinants of a large informal sector and a high level of conflict between capital and labor. In Brazil the extremely detailed apparatus established in the laws and administrative provisions and the lack of continual bargaining among representative parties make the need for a third party interference very frequent. Moreover, management and labor are organized under a peculiar system in which their respective institutions (both called unions) are financially supported by compulsory contributions paid by affiliate and non-affiliate members. This makes effective representation difficult.

\section{Social protection and employment protection}

The two countries are quite different regarding the level of wages and benefits which are much higher in Germany than in Brazil. However, the non-wage labor costs are considerable in both countries. In Brazil this is extremely difficult to be obeyed by small enterprises, where informality is high. An important difference occurs in the area of job protection. Germany has a law which prevents dismissals of about $60 \%$ of public and private jobs. Brazil opted by a severance pay system applied to about $50 \%$ of the workforce-the formal sector. In Germany dismissal can be contested by the employee and the impasses are resolved in court. In Brazil the severance payment system provides no right to contest. But the freedom to dismiss with no cause is costly just as in Germany. However, the protected group in Germany is formed by highly skilled employees, whom companies would keep even in the absence of protective laws.

\section{Labor market dualisms}

The labor market in both countries shows some traits of duality stemming from different employment options in terms of employment protection, wage standards and non-wage labor costs. While both countries have a well protected and strongly regulated core labor market, the nature of labor market duality is quite different. Duality in Germany is expressed by the co-existence of core and marginal segments. While open-ended full-time contracts constitute the core, fixed-term contracts, temporary agency work and different forms of part-time work as well as selfemployment can be seen as the more flexible segment of the labor market. Still, both core and margin enjoy the same basic protections of the social security system and, in many aspects, the protections of collective agreements. Duality in Brazil is marked by a protected-the formal sector-and an unprotected segment-the informal sector. 


\section{The role of internal flexibility}

In spite of these differences, the two countries have similar mechanisms of internal and external flexibility such as hours account, working-time arrangements, salary adjustments, fixed-term contracts, part-time work, temporary jobs and layoff. The differences are in the intensity and the outcomes of these mechanisms. In Germany, for instance, internal flexibility is the core mechanism to stabilize jobs in a volatile economic environment and mainly implemented with the consent of the collective bargaining parties and plant-level actors. In Brazil, labor unions, the General Prosecutor and most judges tend to block their use. Under a limited basis, some flexible measures were used by in a few cases during the 2008-09 crisis. In spite of their pitfalls, they helped the companies and the employees to cope with economic difficulties, with jobs being preserved in most cases. More extensive use was avoided due to labor unions resistance and the fear of an eventual interference by the courts.

\section{Education and training}

One of the most striking differences between the two countries refers to the quality of labor. Germany has an advanced educational system, which is crucial to support the technological needs of a developed economy. The "dual system" of vocational education guarantees the high competence of the country's workforce. Brazil is still struggling with education. Although several advances have accomplished in the primary level, there is a long way to go in order to place Brazil among the well educated countries. This is limits functional flexibility. The majority of workers are not able to perform different tasks in a system of job rotation. In Germany the high quality of labor-both at the core and at the margin-facilitates adjustments under different working situations and is one driving force of internal flexibility.

\section{Policy implications}

In spite of their differences, both countries performed reasonably well in the 2008-09 crisis. Unemployment affected only a relatively small part of the workforce. Many jobs were saved by using the available flexible measures and recovery has been rapid. However, some issues have remained.

\section{Lessons for Germany}

There is some need to close the regulatory gap between core and marginal jobs to ensure better transitions into permanent jobs. This would imply, in particular, a recalibration of employment protection for permanent jobs relative to fixed-term contracts and more effective equal pay regulation in temporary agency work after an initial employment spell. Furthermore, there are persistent difficulties with respect to labor market entry of early school leavers and low-skilled adults. Stronger and more targeted public investment into activation and education is needed. 


\section{What Brazil needs to change}

The need for a respected bargaining is evident. High non-wage labor costs could be tolerated if a large part of these costs were negotiable. This would certainly reduce the portion of informal labor-particularly among the employees of small enterprises.

The transition from law to negotiation is not easy due to historical and cultural factors which were behind the creation of a paternalistic system to protect the poor. The teaching of labor law and the formation of the labor lawyers and judges has been under the philosophy of full legalistic protection, which has inhibited the development of a respected bargaining culture.

Changing this culture will take time. However, the pressures coming from competition of the global economy may speed up change. Brazil is losing ground in the export of manufactured products and is facing difficulties competing with imported goods, mainly from Asia and Eastern Europe.

It seems more plausible to carry out these changes step by step rather than trying to revamp the whole system. A few cases of success illustrate the feasibility of this strategy as the creation special programs for small enterprises (Simples and Supersimples programs) as well as the recent reduction of non-salary costs for selected sectors, such as textile, shoes and IT.

In any case, a durable change will require strong leadership from the government and full respect of acquired labor rights. Labor reform has to assure the rights of those who have them (formal market) and to extend these rights to those who do not have any (informal market). More important will be to limit the role of the courts in ruling out agreements made by mature parties involved in free collective bargaining.

Key corrections in the existing job protection institutions seem in order. There is no reason to have the present severance pay system disconnected from the pension fund. In every dismissal today, workers use the resources accumulated in the severance fund (FGTS). They should be stimulated to accumulate these resources to be used to improve their pensions on retiring.

Finally, a continual improvement of education and vocational training is a crucial task to operate active labor market policies. 


\section{References}

Almeida, R. and Carneiro, P. (2007): "Inequality and Employment in a Dual Economy: Enforcement of Labor Regulation in Brazil”, IZA Discussion Paper, No. 3094.

Atkinson, J. (1984): "Flexibility, Uncertainty and Manpower Management", IMS Report, No. 89.

Bach, H.-U., et al. (2009): "Die Krise wird deutliche Spuren hinterlassen", IAB Kurzbericht, No. 20/2009.

Baltar, P.E. et al. (2010): "Trabalho no governo Lula: uma reflexão sobre a recente experiencia brasileira”, Global Labour University Working Papers, No. 9.

Bassanini, A.P. and Duval, R. (2006): "Employment Patterns in OECD Countries: Reassessing the Role of Policies and Institutions", OECD Economics Department Working Paper, No. 486.

Blanchard, O. (2006): "European Unemployment: The Evolution of Facts and Ideas", Economic Policy, 21(45), 5-59.

Boockmann, B. and Hagen, T. (2006): "Befristete Beschäftigungsverhältnisse: Brücken in den Arbeitsmarkt oder Instrumente der Segmentierung?", ZEW Wirtschaftsanalysen: Schriftreihe des ZEW, Band 80.

Bulhões, M.G.P. (2004): "Plano Nacional de Qualificação do Trabalhador: PLANFOR", São Paulo em Perspectiva, 8(4), 39-49.

Caliendo, M. (2009): “Income Support Systems, Labor Market Policies and Labor Supply: The German Experience", IZA Discussion Paper, No. 4665.

Cechin, J. and Fernandes, A.Z. (2000): "Boletim Informativo GFIP: Avaliação dos Dados", Ministério da Previdência e Assistência Social, 1(2).

Chahad, J.P. (2002): "Um novo desenho do programa brasileiro de seguro-desemprego", in Chahad, J.P. and Fernandes, R. (eds.), O Mercado de Trabalho no Brasil: políticas, resultados e desafios, São Paulo: Fundação Instituto de Pesquisas Econômicas.

Chahad, J.P. (2006): "Políticas ativas e passivas no Mercado de trabalho", mimeo.

Dustmann, C., Ludsteck, J. and Schönberg, U. (2009): "Revisiting the German Wage Structure", Quarterly Journal of Economics, 124(2), 843-881.

Ebbinghaus, B. and Eichhorst, W. (2009): "Employment Regulation and Labor Market Policy in Germany, 1991-2005", in de Beer, P. and Schils, T. (eds.), The Labour Market Triangle Employment Protection, Unemployment Compensation and Activation in Europe, Cheltenham: Edward Elgar.

Eichhorst, W., Grienberger-Zingerle, M. and Konle-Seidl, R. (2008): “Activation Policies in Germany: From Status Protection to Basic Income Support", in Eichhorst, W., 
Kaufmann, O. and Konle-Seidl, R. (eds.), Bringing the Jobless into Work?, Berlin: Springer.

Eichhorst, W., Marx, P. and Tobsch, V. (2009): “Institutional Arrangements, Employment Performance and the Quality of Work", IZA Discussion Paper, No. 4595.

Eichhorst, W. and Marx, P. (2011): "Reforming German Labour Market Institutions: A Dual Path to Flexibility", Journal of European Social Policy, 21(1), 73-87.

Enste, D.H. and Schneider, F. (2011): Jahrbuch Schattenwirtschaft 2010/2011: Schwarzarbeit, Steuerhinterziehung und Finanzkrise, Berlin: LIT.

França, M.M. (2011):“A Justiça do Traalho no Brasil: atuação e regularidade dos processos pendentes no TST", São Paulo: Edição do CIEE.

Freier, R. and Steiner, V. (2008): “'Marginal Employment': Stepping Stone or Dead End? Evaluating the German Experience", Zeitschrift für Arbeitsmarktforschung, 41(23), 223-243.

Fuchs, J. et al. (2010a): “Entwicklung des Arbeitsmarktes 2010: Die Spuren der Krise sind noch länger sichtbar", IAB Kurzbericht, No. 3/2010.

Fuchs, J. et al. (2010b): "Der Arbeitsmarkt schließt an den vorherigen Aufschwung an", IAB Kurzbericht, No. 18/2010.

Fuchs, Johann et al. (2011): “Rekorde und Risiken”, IAB Kurzbericht, No. 7/2011.

Hohendanner, C. (2010): “Unsichere Zeiten, unsichere Verträge?”, IAB Kurzbericht, No. $14 / 2010$.

IPEA (2009): "Carga horária de trabalho: evolução e principais mudanças no Brasil", Instituto de Pesquisa Econômica Aplicada, No. 24.

Jacob, O. (2010): Sector informal y políticas públicas em América Latina, Rio de Janeiro: Konrad Adenauer Stiftung.

Menezes Filho, N. (2011): “Curso técnico eleva 12\% o salário”, Valor 22/07/2011.

Möller, J. (2010): "The German Labor Market Response in the World Recession: Demystifying a Miracle", Zeitschrift für Arbeitsmarktforschung, 42(4), 325-336.

Nascimento, A.M. (2005): Compêndio de direito sindical, São Paulo: Editora LTR.

Neri, M. and Fontes, A. (2010): "Brasil", in Sector informal y políticas públicas em America Latina, Rio de Janeiro: Konrad Adenauer Stiftung.

Nickell, S. (1997): “Unemployment and Labor Market Rigidities: Europe versus North America", Journal of Economic Perspectives, 11(3), 55-74.

Nickell, S., Nunziata, L. and Ochel, W. (2005): "Unemployment in the OECD since the 1960s. What Do We Know?”, The Economic Journal, 115(500), 1-27.

OECD (2010): OECD Employment Outlook, Paris: OECD. 
Pastore, J. and Skidmore, T.E. (1985): “Brazilian Labor Relations: A New Era?” in Juris, H. et al. (eds.), Industrial Relations in a Decade of Economic Change, Madison: Industrial Relations Research Association.

Pastore, J. (2003): Reforma sindical: para onde o Brasil quer ir?, São Paulo: Editora LTR.

Pastore, J. (2011): "O papel do Estado na flexibilização das leis do trabalho", in Filho, I.G. and Meyer-Pflug, S.R. (eds.), A intervenção do Estado no domínio econômico: condições e limites, São Paulo, Editora LTR.

Robortella, L.C. (2011): "Intervenção do Estado, diálogo social e transformações do mercado de trabalho", in Filho, I.G. and Meyer-Pflug, S.R. (eds.), A intervenção do Estado no domínio econômico: condições e limites, São Paulo, Editora LTR.

Schank, T., Schnabel, C. and Stephani, J. (2009): "Geringverdiener: Wem und wie gelingt der Aufstieg?", Jahrbücher für Nationalökonomie und Statistik, 229(5): 584-614.

Simão, A.R.A. (2009): Sistema de vigilância e fiscalização do trabalho no Brasil: efeitos sobre a expansão do emprego formal no período 1999-2007, Brasília: IPEA.

Streeck, W. (1992): "Productive Constraints: on the Institutional Conditions of Diversified Quality Production", in Streeck, W. (ed) Social Institutions and Economic Performance: Industrial Relations in Advanced Capitalist Economies, London and Beverley Hills: Sage.

Thelen, K. (2004): How Institutions Evolve: The Political Economy of Skills in Germany, Britain, the United States and Japan, Cambridge: Cambridge University Press.

Thelen, K. and Busemeyer, M.R. (2008): "From Collectivism Towards Segmentalism. Institutional Change in German Vocational Training", MPIfG Discussion Paper, No. 08/13.

World Bank (2011): Envelhecendo em um Brasil mais velho, Washington.

Zylberstajn, H. (2005): "President Lula's union reform", paper presented at the 5th Regional American Congress of Industrial Relations, in Santiago. 